\title{
Functional foods for dyslipidaemia and cardiovascular risk prevention
}

\author{
Cesare R. Sirtori ${ }^{1}{ }^{*}$, Claudio Galli ${ }^{1}$, James W. Anderson ${ }^{2}$, Elena Sirtori ${ }^{3}$ and Anna Arnoldi ${ }^{3}$ \\ ${ }^{1}$ Department of Pharmacological Sciences, University of Milano, Italy \\ ${ }^{2}$ Department of Internal Medicine, University of Kentucky, Lexington, KY, USA \\ ${ }^{3}$ Department of Endocrinology, Pathophysiology and Applied Biology, University of Milano, Italy
}

\begin{abstract}
A food can be regarded as 'functional' if it can demonstrate a beneficial efficacy on one or more target functions in the body in a convincing way. Beyond adequate nutritional qualities, functional foods should either improve the state of health and wellbeing and/or reduce the risk of disease. Functional foods that are marketed with claims of heart disease reduction focus primarily on the major risk factors, i.e. cholesterol, diabetes and hypertension. Some of the most innovative products are designed to be enriched with 'protective' ingredients, believed to reduce risk. They may contain, for example, soluble fibre (from oat and psyllium), useful both for lowering cholesterol and blood pressure, or fructans, effective in diabetes. Phytosterols and stanols lower LDL-cholesterol in a dose-dependent manner. Soya protein is more hypocholesterolaemic in subjects with very high initial cholesterol and recent data indicate also favourable activities in the metabolic syndrome. $n$-3 Fatty acids appear to exert significant hypotriacylglycerolaemic effects, possibly partly responsible for their preventive activity. Dark chocolate is gaining much attention for its multifunctional activities, useful both for the prevention of dyslipidaemia as well as hypertension. Finally, consensus opinions about tea and coffee have not emerged yet, and the benefits of vitamin $\mathrm{E}$, garlic, fenugreek and policosanols in the management of dyslipidaemia and prevention of arterial disease are still controversial.
\end{abstract}

CVD prevention: Diabetes: Diet: Functional foods: Hypercholesterolaemia: Nutraceuticals

\section{Introduction}

CVD, a major cause of death in Western populations and a constantly growing cause of morbidity and mortality worldwide $^{(1)}$, can be prevented by lifestyle changes, one of which is diet. Lifestyle changes including diet may reduce the risk for premature CHD by $82 \%$, whereas nutritional practices alone may reduce the risk by $60 \%{ }^{(3)}$. Epidemiological and clinical studies indicate that the risk of CHD and hypertension is reduced by a diet rich in fruits, vegetables, unrefined grains, fish and low-fat dairy products, and low in saturated fats and $\mathrm{Na}$. Individuals who adopt this diet benefit by way of a much lower risk of heart disease ${ }^{(4,5)}$. Such diets require, however, major changes in habits and frequently do not fit with what Westerners eat today. Being aware of this fact, the food industry has started to market products labelled as 'functional foods'. Since this term has not yet reached a standard nutritional meaning, regulatory agencies and professional associations of nutrition scientists still use different definitions. International Life Sciences Institute (ILSI) Europe, an industry-sponsored forum in which representatives from industry, academia and government address nutritional issues, proposed a definition which briefly runs (http://europe.ilsi.org/NR/rdonlyres/95A18 EA7-2EE8-401B-A27E-0950EC0AA965/0/SynthesisFinal Document22jn09sv.pdf): 'The term functional foods refers to foods that are consumed as part of a normal food pattern and that have beneficial effects on body functions that go beyond adequate nutritional effects and that are relevant to an improved state of health and well-being and/or a reduction of the risk (not prevention) of disease.'

Functional foods marketed with the claim of reduction of heart disease risk focus primarily on any risk factor, i.e. blood cholesterol, diabetes and hypertension. In the past, this was achieved mainly by a reduced content of a specific food component known to increase risk, i.e. Na or saturated fats. More recently, products have been designed to be enriched with 'protective' ingredients believed to reduce risk, mainly by acting on serum lipids. The most common 'protective' ingredients are fibres, long-chain $n$-3 fatty acids, phytostanols and sterols as well as nutrients based on or enriched with vegetable proteins, mainly soya.

\footnotetext{
Abbreviations: ALA, $\alpha$-linolenic acid; HDL-C, HDL-cholesterol; LDL-C, LDL-cholesterol; LDL-R, LDL receptor; SREBP, sterol regulatory element-binding protein.

* Corresponding author: Dr Cesare R. Sirtori, fax +39 25021 8284, email cesare.sirtori@unimi.it
} 


\section{Carbohydrates and fibres}

Increasing carbohydrate consumption can exert direct effects on the lipoprotein profile. Raising dietary carbohydrates, while decreasing fat consumption, decreases cholesterolaemia, LDL-cholesterol (LDL-C) and TAG, but it may also lower HDL-cholesterol (HDL-C) concentrations $^{(6)}$.

Fasting and postprandial TAG responses may depend upon the fibre content of the diet. High-carbohydrate-lowfibre diets increase fasting serum $\mathrm{TAG}^{(7)}$, whereas highcarbohydrate-high-fibre diets reduce $\mathrm{TAG}^{(8,9)}$. Short-term (3-4 weeks) intake of a high-carbohydrate-low-fibre diet may increase fasting TAG significantly by $>50 \%$, but over a similar time period consumption of a high-carbohydratehigh-fibre diet may decrease serum TAG by $10 \%$ or more ${ }^{(9)}$. Long-term intake of a moderately high-carbohydrate-highfibre diet significantly decreases serum cholesterol and LDL-C without significantly altering HDL-C or TAG ${ }^{(10)}$.

Diets with a lower glycaemic index are associated with significantly higher HDL-C values $v$. diets with a higher glycaemic index ${ }^{(11,12)}$. The comparison of a high-fibre Mediterranean diet with a low-carbohydrate diet for weight management ${ }^{(13)}$ led to similar weight losses, but the highfibre diet showed more favourable effects on lipids (LDL-C reduction $-5.6 \%$ with the high-fibre $v .-3.0 \%$ with the low-carbohydrate diet). Very recently a low-glycaemic index diet, i.e. emphasising low-glycaemic index breads, cereals, pasta, parboiled rice, beans, peas and nuts, was compared with a high-cereal-low-fibre diet with a similar energy intake. These diets were given for 6 months to 210 participants with type 2 diabetes. In addition to a more marked improvement in $\mathrm{HbA}_{1 \mathrm{c}}$ levels, the low-glycaemic index diet increased HDL-C by $17 \mathrm{mg} / \mathrm{l}$, compared with a reduction of $2 \mathrm{mg} / \mathrm{l}$ in the high-cereal-low-fibre $\operatorname{diet}^{(14)}$.

Dietary fibres are recommended as a safe and practical approach for cholesterol reduction. This activity is limited to soluble fibres, whereas insoluble fibres (cellulose + lignin) do not $^{(9)}$. Soluble fibres known to lower LDL-C ${ }^{(15)}$ include pectins from apples and citrus fruits, $\beta$-glucan from oats and barley, and fibres from flaxseed and psyllium. A recent paper ${ }^{(16)}$ suggests also a potential application in this field of lupin fibre. The cholesterol-lowering effects of soluble fibres are in the order of 5-10\%. The mechanisms of these effects are not fully understood in all cases. An important one is the binding of bile acids, but inhibition of cholesterol synthesis by SCFA, produced by fermentation in the colon, is also hypothesised ${ }^{(17)}$.

Studies with soluble fibres, way back from early reports on oat bran ${ }^{(18)}$ and psyllium ${ }^{(19)}$, clearly established their hypocholesterolaemic efficacy. This was well confirmed in two meta-analyses ${ }^{(20,21)}$ and led to health claims for foods or supplements containing these ingredients ${ }^{(22)}$. Psyllium is the most effective soluble fibre for reducing cholesterolae$\mathrm{mia}^{(23)}$ : it leads to LDL-C reductions of about $7 \%$ after intakes of $10 \mathrm{~g} / \mathrm{d}$ (divided into two portions) ${ }^{(20)}$, sustained for up to 24 weeks of follow up ${ }^{(24)}$. Daily intake of psyllium is also associated with insignificant decreases of HDL-C $(-1.3 \%)$ and insignificant increases in fasting TAG $(+0.4 \%)^{(25)}$
Soluble oat fibre is mainly composed of $\beta$-glucan. In hypercholesterolaemic individuals the consumption of $4-6 \mathrm{~g}$ of this functional ingredient may significantly lower total cholesterol and LDL-C in the range of $8-12 \%$ $(\text { Table } 1)^{(26-28)}$. $\beta$-Glucan from oat incorporated into a fruit drink was shown to lower total cholesterol and LDL-C by, respectively, 4.8 and $7.7 \%$ (both $P<0.01$ ) also in normolipidaemics ${ }^{(29)}$. This was associated with a significant reduction of both cholesterol and bile acid absorption and partially also with an impaired synthesis.

Another convenient source of $\beta$-glucan is barley. Confirmation of the effects of concentrated barley $\beta$-glucan on blood lipids was obtained in a 10-week controlled study ${ }^{(30)}$, where concentrated barley $\beta$-glucan was given to hypercholesterolaemic individuals at two different doses ( 3 and $5 \mathrm{~g} / \mathrm{d}$ ). Both high-molecular-weight and low-molecular-weight barley $\beta$-glucans proved to be effective in LDL-C lowering, mean reductions being $9 \%$ for the $3 \mathrm{~g}$ and $13-15 \%$ for the $5 \mathrm{~g}$ dose. Target levels of LDL-C values were obtained in some of these individuals, thus indicating a definite potential clinical benefit of barley $\beta$-glucan.

There is also a special interest today in fructans, i.e. oligo- and poly-fructosyl polymers, which provide an example of mixed activities of fibre and digestible polysaccharides. Inulin, a poly-fructosyl polymer, does not have hypocholesterolaemic effects but may decrease serum $\mathrm{TAG}^{(31)}$. Inulin-type fructans are natural components of the daily diet (asparagus, garlic, onions, etc). Once ingested, they are largely fermented by the colonic bacterial strains such as bifidobacteria, leading to important intestinal systemic effects. Oligofructose, a short-chain fructan obtained from chicory root inulin, protects rats against liver TAG accumulation induced by fructose and, to lesser extent, against steatosis occurring in obese rat strains ${ }^{(32)}$. Fructan linkages may be hydrolysed under mild acidic conditions, but a larger amount of fructan oligomers are absorbed intact across the intestinal mucosa and recovered almost entirely in urine. Oligofructoses can reduce postprandial glycaemia and insulinaemia in rats as well as lower TAG in blood and liver in rats and hamsters ${ }^{(33)}$. These products, in particular inulin-type fructans extracted from chicory roots, may raise the production of incretins by endocrine intestinal mucosal cells. It is noticeable that as a result these products can decrease mean daily energy intake and increase the caecal pool of glucagon-like peptide-1 and peptide YY. Increase of these peptides is of particular significance today, when antagonists of glucagon-like peptide-1 hydrolysis have become available as antidiabetic agents (sitagliptin and vildagliptin) ${ }^{(34)}$. In a pilot study ${ }^{(35)}$ $16 \mathrm{~g}$ oligofructose per $\mathrm{d}$ in patients with non-alcoholic steatohepatitis significantly reduced liver enzymes, glucose and insulin levels with a modest effect on triacylglycerolaemia, thus indicating that possibly this type of dietary component could be of benefit in diabetes management. Although some concern has been expressed based on the observation of increased colonic adenoma progression in a mouse model after inulin feeding ${ }^{(36)}$, the clinical impact of this finding remains elusive and should not deter from the present-day preventive value of prebiotics. 


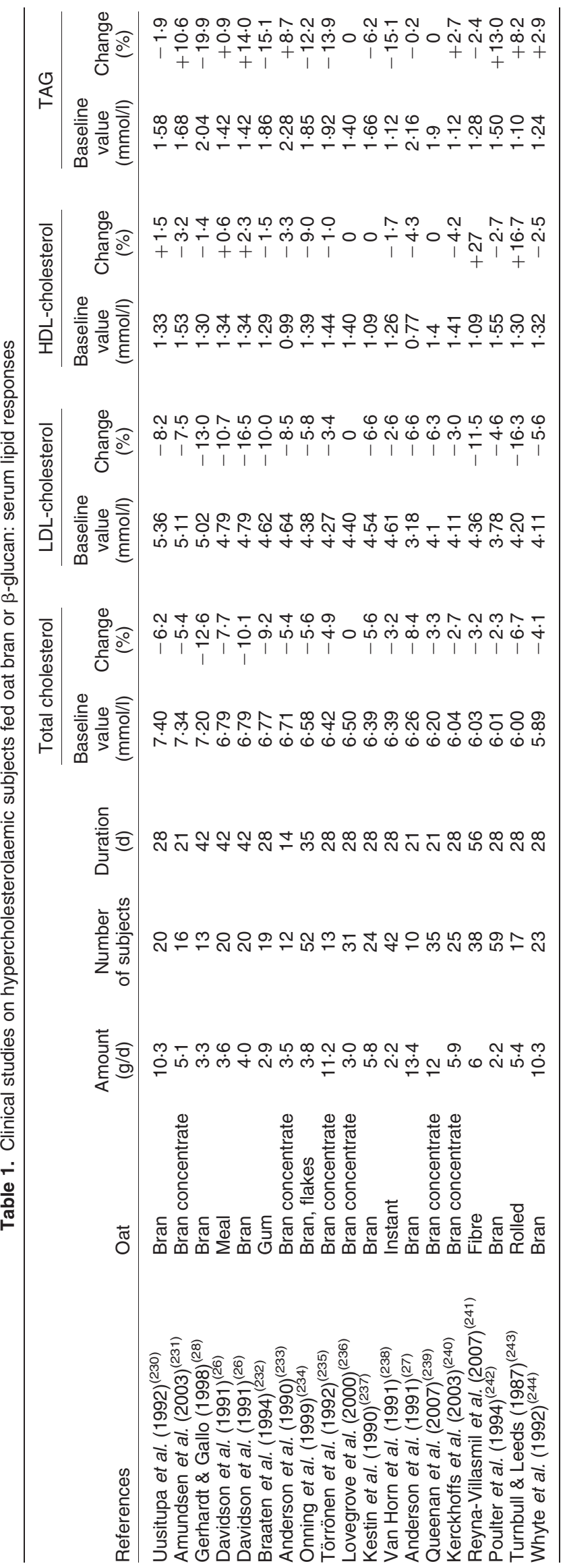

\section{n-3 Fatty acids}

Long-chain PUFA of the $n-3$ series, for example, EPA $(20: 5 n-3)$ and DHA $(22: 6 n-3)$, are provided in the diet almost exclusively by animal foods (especially fish). In addition, the shorter-chain metabolic precursor of the $n-3$ long-chain PUFA, i.e. the 18-C $\alpha$-linolenic acid (ALA; $18: 3 n-3)$, is produced and found in various plant foods (for example, spinach, purselane etc), in certain seeds (for example, nuts and flaxseeds) and oils derived from them (for example, linseed, rapeseed, soya, etc). The amounts of ALA in most vegetable fats and oils are, however, much lower than those of the corresponding $n-6$ fatty acid, linoleic acid.

Some general features of the $n-3$ fatty acids are relevant for understanding their unique functions in the body:

(1) They cannot be synthesised de novo in higher organisms, and even the conversion of ingested ALA, the 18-C precursor, to the long-chain derivatives, especially DHA, is very inefficient in humans, being, however, greater in women than in men, whereas linoleic acid is efficiently converted to arachidonic acid (20:4n-6). Therefore, levels of $n$-3 fatty acids in the body depend exclusively upon intakes.

(2) In the body, they are almost exclusively incorporated into structural lipids (mainly glycerophospholipids) and therefore even relatively small intakes result in relevant changes in the proportion of these fatty acids in pools mainly located in biological membranes.

(3) Together with arachidonic acid, the $n-3$ long-chain PUFA play a major role in the modulation of membrane properties (for example, structure and related features, such as 'fluidity') and functions (ion channels, receptor responses, signalling pathways, involving also lipid mediators, such as the eicosanoids and other products of phospholipase activities).

(4) Their requirements may be met with difficulty even with ad hoc dietary strategies, since their presence in the typical diet of most Western countries is very limited.

A list of the main actions and mechanism of $n-3$ fatty acids on the cardiovascular system is provided in Table 2.

After the early observation that populations with a high fish consumption have a low incidence of CVD, for example, in the case of Greenland Eskimos ${ }^{(37,38)}$, interest in the cardiovascular effects of this rather unique type of marine fat (mostly fish fat), particularly abundant in cold water fish, has grown consistently. Although fish per se contains various nutrients with potentially favourable effects on health $(\mathrm{Se}, \mathrm{P}$, iodine, $\mathrm{Fe}$ and $\mathrm{Cu}$, low $\mathrm{Na}$, and selected essential amino acids, for example, methionine, cysteine, lysine and vitamins A, B and D), attention has been immediately focused on the $n-3$ fatty acids in fish and fish-derived products (fish oils). As a consequence, over the years products enriched in $n$ - 3 longchain PUFA (fish oil capsules) or purified preparations as TAG or ethyl esters have been used for the prevention and treatment of disease. Although, as predictable, bioavailability of the fatty acids is appreciably higher when ingested through fish ${ }^{(39,40)}$, the advantages of using ad hoc standardised preparations for long-lasting treatments are obvious. 
Table 2. Main actions and mechanisms of the effects of long-chain $n-3$ fatty acids (EPA and DHA) on the cardiovascular system

\begin{tabular}{|c|c|c|}
\hline Target & Effects & Mechanisms and comments \\
\hline \multicolumn{3}{|l|}{ Functional effect } \\
\hline Platelets & Anti-thrombotic & Reduced or modified production of pro-aggregatory eicosanoids $\left(\mathrm{TxA}_{2}\right)$ \\
\hline \multirow[t]{3}{*}{ Inflammatory cells } & Anti-inflammatory & $\begin{array}{l}\text { Reduced production of pro-inflammatory eicosanoids }\left(\mathrm{LTB}_{4}, \mathrm{LTC}_{4}\right) \\
\text { derived from arachidonic acid }\end{array}$ \\
\hline & & $\begin{array}{l}\text { Production of anti-inflammatory mediators (resolvins from EPA and } \\
\text { docosanoids from DHA) }\end{array}$ \\
\hline & & Reduced production of cytokines and adhesion proteins \\
\hline Heart & Anti-arrhythmic & Modulation of ion channels in cardiomyocytes $\left(\mathrm{Ca}^{2+}\right.$ and $\left.\mathrm{Na}^{+}\right)$ \\
\hline Blood pressure & Reduction (few mmHg) & $\begin{array}{l}\text { Enhanced endothelial production of NO and reduced vascular } \\
\text { resistance due to increased fluidity of erythrocyte membranes }\end{array}$ \\
\hline Atherosclerotic lesions & Enhanced plaque stability & $\begin{array}{l}\text { Incorporation of the highly unsaturated } n-3 \text { fatty acids into plaque } \\
\text { lipid pools }\end{array}$ \\
\hline \multicolumn{3}{|l|}{ Metabolic effects } \\
\hline Serum TAG & Reduction & Enhanced fatty acid oxidation, reduced TAG synthesis \\
\hline $\mathrm{HDL}_{2}$-cholesterol & Elevation & Modulation of CETP \\
\hline LDL-cholesterol & Tendency to an increase & $\begin{array}{l}\text { Increase of LDL particles size but not number (i.e. lower number } \\
\text { of less atherogenic particles) }\end{array}$ \\
\hline Total cholesterol & Variable effects & $\begin{array}{l}\text { Increment or reduction depending upon intakes of total fats and } n-3 \\
\text { fatty acids }\end{array}$ \\
\hline
\end{tabular}

$\mathrm{TxA}_{2}$, thromboxane $\mathrm{A}_{2} ; \mathrm{LTB}_{4}$ leukotriene $\mathrm{B}_{4} ; \mathrm{LTC}_{4}$ leukotriene $\mathrm{C}_{4} ; \mathrm{CETP}$, cholesteryl ester transfer protein.

Numerous studies, carried out in the past, have been based on both fish consumption and supplement intakes and have included secondary-prevention (supplements or dietary advice), cohort, and primary-prevention studies, most of them being randomised controlled trials. Outcomes were also diversified: all-cause mortality, cardiac death, sudden death, myocardial infarction and stroke. A general consensus, with only a few exceptions ${ }^{(41)}$, is that the administration of $n-3$ long-chain PUFA has favourable effects on the cardiovascular system.

In addition to the functional mechanisms underlying the cardiovascular preventive activity, i.e. anti-thrombotic (reduced platelet aggregability), anti-inflammatory, modulation of endothelial function, anti-arrhythmic and plaque-stabilising effects, $n-3$ fatty acids exert major metabolic activities. Primary among these is the reduction of serum TAG. Whereas the favourable cardiovascular effects of $n-3$ fatty acids are generally obtained with relatively low doses of the ethyl esters, i.e. about $1 \mathrm{~g} / \mathrm{d}$, more significant triacylglycerolaemic effects may require higher doses.

The recent recommendation of the Nutrition Committee of the American Heart Association specifies that patients without documented CHD should eat oily fish twice weekly; patients with documented CHD should consume about $1 \mathrm{~g}$ EPA + DHA daily, preferably from oily fish, although supplements may be used; individuals with hypertriacylglycerolaemia may be advised to ingest 2 to $4 \mathrm{~g}$ EPA + DHA daily from capsules ${ }^{(42)}$.

A meta-analysis ${ }^{(43)}$ of sixty-five studies reports that fish oil supplements produce these mean changes in serum lipoproteins: total cholesterol, unchanged; LDL-C, $+7.5 \%$; HDL-C, $+2 \%$; TAG, $-27.5 \%$. Studies ${ }^{(43-45)}$ using DHA supplements, 0.7 to $1.5 \mathrm{~g} / \mathrm{d}$, report similar changes: total cholesterol, +7.0; LDL-C, +10.3\%; HDL-C, $+3.3 \%$; TAG,$-23.4 \%$. An overview ${ }^{(46)}$ of twelve clinical studies on Omacor $^{\circledR}$, a concentrate of $n-3(4 \mathrm{~g} / \mathrm{d})$, indicates significant lowering of plasma TAG (from -19 to $-47 \%$ ), the best results being obtained in subjects with fasting serum TAG $>5.65 \mathrm{mmol} / \mathrm{l}$. Small increases of LDL-C are, however, associated with this treatment.
The intake of fish oil supplements has the largest impact on individuals with hypertriacylglycerolaemia. For individuals with serum TAG values $<5.6 \mathrm{mmol} / \mathrm{l}$, use of $1-2 \mathrm{~g} n-3$ ethyl ester per $\mathrm{d}$ is likely to induce lesser changes in total cholesterol and HDL-C, 7-10\% increases in LDL-C and $15-25 \%$ reductions in fasting serum TAG. A recent American Dietetic Association commentary suggests, however, that consumption of fish may be better suited for the achievement of $n$-3 long-chain PUFA therapeutic intakes ${ }^{(47)}$.

A concern on the possibility that prolonged intake of $n-3$ fatty acids may lead to an increased risk of diabetes in hyperlipidaemic individuals was raised by a number of investigators ${ }^{(48)}$. A long-term study on 1000 Italian patients followed for up to 1 year, however, failed to detect any significant changes in glycaemic regulation in $n$-3-treated patients ${ }^{(49)}$. Indeed, there was clear evidence of a progressive improvement of HDL-C levels and a trend toward a reduction of LDL-C levels at the end of the study ${ }^{(50)}$.

$n$-3 PUFA from fish oil are involved in a number of nuclear receptor-regulated mechanisms, some of which, for example, liver X-receptor, PPAR, sterol regulatory elementbinding protein (SREBP) and nuclear factor 4- $\alpha$, may regulate tissue lipid metabolism and consequently the associated metabolic and lipoprotein disorders ${ }^{(51)}$. On the basis of in vitro studies, the activation of PPAR $\alpha$ has been proposed to be the most significant. Other mechanisms, i.e. activation of the liver X-receptor, SREBP-1 and nuclear factor 4- $\alpha$, may participate in the lipid-lowering mechanism at steps subsequent to PPAR $\alpha$ activation ${ }^{(48)}$. By all of these mechanisms, $n-3$ fatty acids may not only affect lipidaemia, improving triacylglycerolaemia and also potentially HDLcholesterolaemia $^{(52)}$, but may also improve other atherosclerosis risk factors, in particular hypertension ${ }^{(53)}$.

Very recently support has been given to the possibility of an additive CHD-protective effect of $n-3$ fatty acids given with statins. The Japan EPA Lipid Intervention Study (JELIS) $^{(54)}$ randomised 18645 secondary prevention patients to $1.8 \mathrm{~g}$ EPA per d together with ongoing statin treatment. The authors reported a $19 \%$ relative reduction in 
major cardiovascular events without any changes in total mortality. The low cost of this therapeutic choice and its excellent tolerability suggests this as a potential standard treatment in low-risk populations.

The concomitance of low amounts of $n-3$ fatty acids in our average diet and need for prolonged administration for prevention and treatments has led to the development of selected preparations (enriched foods or special formulations). These should combine acceptability and adequate bioavailability of their relatively low contents of $n-3$ fatty acids. These fatty acids are therefore being incorporated into a number of commercially available, natural foods that, due to rather unique structural features, appear to be particularly suited as efficient fatty acid vehicles. This is the case of $n$ - 3 fatty acids incorporated into cows' milk, i.e. the only food specifically produced in nature with the aim to be consumed by rapidly growing organisms requiring high fat intakes. In milk, fat is highly dispersed into microglobules that greatly facilitate fat digestion and absorption. The administration of milk enriched with $n-3$ fatty acids, providing about $300 \mathrm{mg}$ of these fatty acids per d (i.e. about 120-140 mg EPA/d and 180-200 mg DHA/d in both of studies), to healthy subjects resulted indeed in plasma $n-3$ fatty acid elevation and in the reduction of serum TAG ${ }^{(55,56)}$.

Formulation of other types of food should, however, define the optimal chemical structure (ethyl esters, TAG or phospholipids) and the best formulation for the incorporation into foods, including the presence of adequate amounts of antioxidants in order to prevent their degradation by auto-oxidation. A cautionary note was recently published on the possibility that $n-3$ intake from fish may be associated with increased intakes of methylmercury and other contaminants, also including dioxins and polychlorinated biphenyls ${ }^{(57)}$. While the authors point out that low-level methylmercury may adversely affect early neural development, the potential toxicity of commercial preparations appears to be very low.

While research interests in the effects of $n-3$ fatty acids have been focused mainly on the long-chain compounds, the role of $n-3$ ALA, typically present in certain plants and plant-derived products, for example, flaxseed oil, walnut oil, zero-erucic rapeseed oil, should also be considered. Although this fatty acid, precursor to EPA and DHA, can be converted to some extent into $\mathrm{EPA}^{(58)}$, the overall conversion to DHA is rather inefficient ${ }^{(59)}$.

ALA has been studied in a limited number of investigations: so far, some epidemiological studies $(60,61)$ and a few mechanistic ones ${ }^{(62,63)}$ suggest a potential cardiovascular protection by this unsaturated fatty acid. The opinions, however, on this topic are still divided. The UK Food Standards Agency workshop considered that the evidence was still equivocal $^{(64)}$, whereas a recent review ${ }^{(65)}$ has concluded that, although ALA supplementation may cause small decreases in fibrinogen concentrations and fasting plasma glucose, most cardiovascular risk markers do not appear to be affected. Thus, dietary supplementation with ALA to reduce CVD cannot be directly recommended, except as being part of a healthy diet. However, the essentially inexhaustible supply of this fatty acid obtainable from plant sources suggests that the research should be continued ${ }^{(66)}$.

\section{Plant sterols and stanols}

All plants produce sterol compounds, also termed phytosterols, chemically related to cholesterol. The average consumption from foods in adults is about $160-350 \mathrm{mg} / \mathrm{d}$, i.e. intakes that do not appreciably alter cholesterol metabolism, whereas an increased intake of phytosterols reduces the intestinal absorption of dietary and biliary cholesterol. This has been the basis for the development of phytosterol-enriched functional foods. The mechanism of reduced cholesterol absorption is believed by some authors to occur by interference with the Niemann-Pick C1-like 1 (NPC1L1) transporter ${ }^{(67)}$, but contrasting findings have been provided ${ }^{(68)}$. The most likely mechanism is micellar competition with cholesterol within the small intestine. The final outcomes are alterations in serum lipoproteins with significant decreases in LDL-C concentrations ${ }^{(69-76)}$.

The major plant sterols ( $\beta$-sitosterol and campesterol) can be saturated using commercial processes to form stanols (sitostanol and campestanol). Sterols or stanols can be incorporated into functional foods, such as reduced-fat spreads (for example, margarines), salad dressings, yogurts, bars, juices and other beverages ${ }^{(77)}$. Esterification of sterols and stanols with fatty acids to form sterol and stanol esters makes them more fat soluble and allows a more effective incorporation into fat-containing foods ${ }^{(69,78)}$. Recently, capsule and tablet formulations of phytosterols have been made available, apparently with similar hypolipidaemic efficacy ${ }^{(77)}$. It is suggested by some authors, but not by others, that plant sterols may, in the long run, suppress bile acid synthesis, particularly in concomitantly statin-treated patients, thus reducing their cholesterol-lowering potential ${ }^{(79)}$.

Phytosterols and phytostanols have similar hypocholesterolaemic efficacy, whereas possible differences in fatsoluble vitamin absorption are disputed ${ }^{(80,81)}$; effectiveness on serum LDL-C levels is similar even when used in functional foods with a low fat content ${ }^{(82,83)}$. There is also controversy as to whether either sterols or stanols provide a better option for cardiovascular prevention ${ }^{(84)}$. Comparative studies have, however, failed to detect any difference in the cholesterol-lowering effects of sterol- $v$. stanol-enriched margarines at $2 \mathrm{~g}$ daily doses ${ }^{(84,85)}$. There is also the possibility of esterifying fatty acids with plant sterols, thus achieving improved activity on the LDL-C:HDL-C ratio ${ }^{(86)}$.

Relevant clinical studies on phytosterols and stanols are listed in Table 3 . Very recently, in a meta-analysis ${ }^{(87)}$ on eighty-four trials including 141 trial arms, a pooled reduction of LDL-C of $0.34 \mathrm{mmol} / 1$, i.e. $8 \cdot 8 \%$, for a mean daily dose of $2.15 \mathrm{~g}$ phytosterols was established. The authors indicate maximal LDL-C reduction (i.e. about $13 \%$ ) with daily doses of 3-4g, whereas higher doses, i.e. up to $8-9 \mathrm{~g} / \mathrm{d}$, do not appear to provide a more effective reduction. The effect is significantly correlated with baseline LDL-C concentrations, explaining $16 \%$ of the variation in residuals $(r-0.4 ; P<0.0001)$. Food format seems to influence the response: at high daily doses, the maximal estimated LDL-C-lowering effect of solid foods was $5.2 \%$ larger than that of liquid foods ${ }^{(87)}$; however, at low daily doses, the dose-response curve is steeper for liquid $v$. solid foods. A recent meta-analysis has shown that 


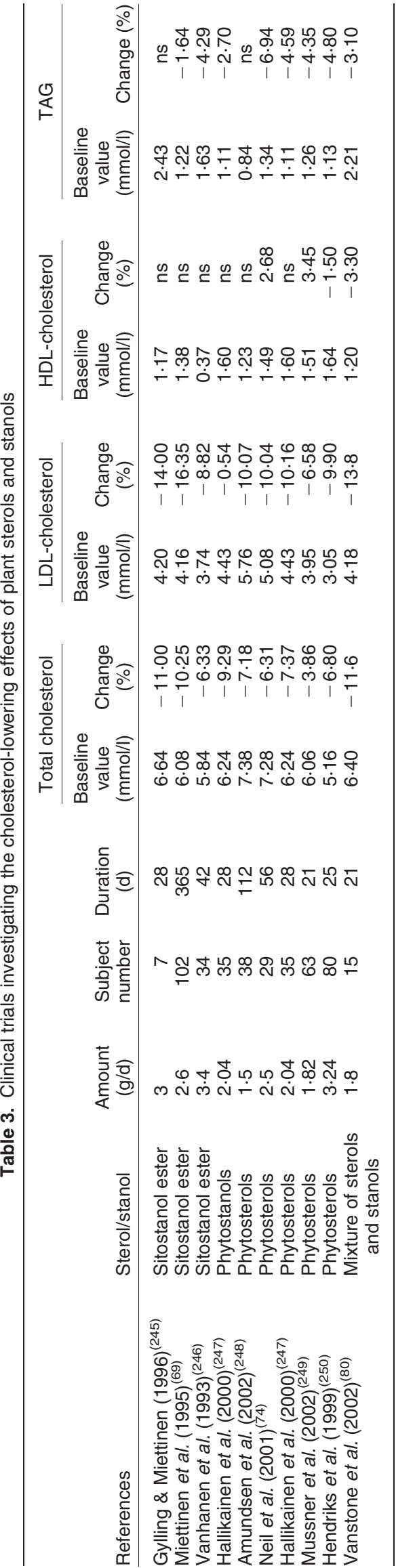

phytosterols dispersed in orange juice are less effective than when they are given in milk or yoghurt ${ }^{(88)}$.

In addition the relative LDL-C-lowering effect is more pronounced when phytosterols are consumed in multiple daily intakes $v$. single daily intakes (mean of $-8.91 v$. $-6.14 \%$ at similar daily doses). Age appears to influence the effect: a highly significant LDL-C-reducing effect $(-14 \%)$ was reported in prepubertal children with familial hypercholesterolaemia without, however, any improvement in vascular endothelial function ${ }^{89)}$.

Both the Nutrition Committee of the American Heart Association $^{(42)}$ and the Adult Treatment Panel III of the National Cholesterol Education Program ${ }^{(90)}$ recommend the use of plant sterols and stanols to decrease serum LDL-C levels. There are, however, concerns about margarines containing plant sterols and stanols, related to the energy intake associated with consuming $>2 \mathrm{~g}$ daily and whether consumers consistently achieve these goals ${ }^{(91)}$.

In an effort to improve the LDL-C lowering by plant sterols, combination therapy with fibres has been attempted. Cookies with 7.6-8 g psyllium per $\mathrm{d}$ and $2.6 \mathrm{~g}$ daily of plant sterols allow an LDL-C reduction of $9 \%$, again with a modest rise of triacylglycerolaemia; there is also evidence of an increased LDL receptor (LDL-R)-mediated uptake ${ }^{(92)}$. The possibility of administering plant stanol esters in a water-soluble form was investigated ${ }^{(93)}$ by testing the combination of soluble $\beta$-glucan from oat with plant stanol esters, i.e. $5 \mathrm{~g}$ with or without $1.5 \mathrm{~g}$ plant stanols. The combination further reduced LDL-C by $9.6 \%$, compared with control muesli, and by $4.4 \%$ compared with $\beta$-glucan muesli, confirming an additive activity of the two agents. Similarly, a water-soluble formulation of plant sterol esters in orange juice significantly reduced both total $(-5 \%)$ and LDL-cholesterolaemia $(-9.4 \% ; P<0.001)$ compared with baseline and placebo beverages ${ }^{(94)}$. Interestingly, a significant reduction of C-reactive protein concentrations $(-12 \%)$ was observed with the sterol beverage.

The lipid-lowering effect of phytosterols can be synergistic and complementary to those of $n-3$ fatty acid: in particular, the combination of phytosterols with longchain $n-3$ fatty acid reduces plasma cholesterol by $13.3 \%$, i.e. more effectively than long-chain $n-3$ fatty acid alone ${ }^{(95)}$.

Both in the USA and in Europe phytosterols are officially functional ingredients. The American Food and Drug Administration approved the health claims for plant sterol and stanol esters and the prevention of risk of CHD in 2000 (http://www.fda.gov/Food/Labeling Nutrition/LabelClaims/HealthClaimsMeetingSignificant ScientificAgreementSSA/ucm074747.htm); the European Food Safety Authority approved a similar claim in 2008 (www.efsa.europa.eu/cs/BlobServer/Scientific_Opinion/ nda_op_ej825_art_14_0038_plant_stanol_ester_en.pdf? ssbinary $=$ true).

\section{Nuts}

Nuts, generally perceived as being unhealthy because of their high fat content, have instead recently shown potential health benefits, since a number of epidemiological and intervention studies indicated favourable plasma lipid responses after their consumption ${ }^{(96,97)}$. A recent review ${ }^{(98)}$ 
considered all clinical studies based on nuts and concluded that the consumption of approximately $50-100 \mathrm{~g}$ (i.e. approximately $1.5-3.5$ servings) of nuts at least five times per week, as part of a heart-healthy diet with a $35 \%$ total fat content (high in MUFA and/or PUFA), may decrease total cholesterol between 2 and $16 \%$ and LDL-C between 2 and $19 \%$ in normo- and hyperlipidaemic individuals. Prospective data from the Physicians' Health Study ${ }^{(99)}$ indicated a strikingly reduced risk of sudden cardiac death associated with nut consumption.

Among tree nuts, walnut may be the most desirable, because of its peculiar composition, such as having a low lysine:arginine ratio, high levels of arginine, folate, fibre, tannins and polyphenols, and being very rich in ALA. Consumption of just four walnuts per $\mathrm{d}$ may provide an optimal daily intake of this essential fatty acid. Feldman reviewed $^{(100)}$ the effects of walnut intake on the main biomarkers of atherosclerotic disease or disease outcome in six controlled intervention studies in primarily healthy, normo- or hyperlipidaemic subjects. In hyperlipidaemics a 4-5\% decrease of total cholesterol follows the consumption of about $50-55 \mathrm{~g}$ walnuts per $\mathrm{d}$.

Hazelnut is another shell-nut that has attracted interest for its fatty acid composition (very similar to olive oil), richness of fat-soluble vitamins, essential minerals (Se), antioxidants and phenolics (caffeic acid), soluble fibre and phytochemicals $^{(101)}$. In a recent controlled investigation ${ }^{(102)}$ on fifteen hypercholesterolaemic men given a hazelnutenriched diet ( $40 \mathrm{~g} / \mathrm{d}$, i.e. $11.6 \%$ of total energy), there was no change in body weight, but clear reductions of VLDLcholesterol, TAG and apo B (respectively $-29.5,-31.8$ and $-9.2 \%)$ as well as small reductions in total cholesterol and LDL-C $(-5 \cdot 2 ;-3.3 \%)$ with increased HDL-C $(+12.6 \%)$, all statistically significant. With dietary guidance many individuals may be able to incorporate the $240 \mathrm{kcal}(1004 \mathrm{~kJ})$ from hazelnuts into their diet, in order to achieve favourable changes in lipid parameters without weight gain. Other beneficial nuts are almonds, also useful for controlling postprandial glycaemia ${ }^{(103)}$, and macadamias ${ }^{(104)}$.

These and other data induced the Food and Drug Administration $^{(105)}$ to authorise a health claim about the relationship between the consumption of nuts and reduced risk of CHD. The new Healthy Eating Pyramid as provided by Willett ${ }^{(106)}$ indicates that one to three servings of nuts and legumes should be incorporated into the diet each day for lifelong health.

\section{Proteins}

\section{Soya proteins}

Soya protein consumption has been shown to successfully reduce cholesterolaemia in experimental animals, when elevated by dietary means ${ }^{(107,108)}$, as well as in humans with cholesterol elevations of genetic or non-genetic ori$\operatorname{gin}^{(109-113)}$. In addition, prospective observational studies, initially in vegetarians ${ }^{(114)}$, then in Chinese women ${ }^{(115)}$ and more recently in a large population in $\operatorname{Japan}^{(116)}$, have shown a reduction of total cholesterol and LDL-C as well as of ischaemic and cerebrovascular events with a daily soya protein intake of more than $6 \mathrm{~g}$, compared with less than
$0.5 \mathrm{~g} / \mathrm{d}$. More recently the 20-year follow-up of the Nurses' Health Study also indicated a significant correlation between vegetable protein intake and reduced cardiovascular risk ${ }^{(117)}$.

In the earliest studies in the 1970s, a soya protein preparation, given to hospitalised hypercholesterolaemic patients, was found to be highly effective for cholesterol lowering and well tolerated. In this controlled cross-over investigation in twenty patients who underwent a 6-week study $^{(109)}$, there was a $20-22 \%$ reduction in total cholesterol level and a $22-25 \%$ reduction in LDL-C, without significant changes of triacylglycerolaemia. The reduction in plasma cholesterol was inversely related to the baseline cholesterolaemia and not modified by the addition of dietary cholesterol ${ }^{(109)}$.

The large number of ensuing clinical studies are summarised in a meta-analysis ${ }^{(118)}$ of thirty-eight studies up to 1995 , in both hypercholesterolaemic and normolipidaemic individuals. This meta-analysis confirmed that serum LDL-C concentrations are modified, dependent on baseline cholesterolaemia, from a minimum of $-7.7 \%$ in subjects with total cholesterol in the normal range $(<2000 \mathrm{mg} / \mathrm{l})$, up to $-24 \%$ in clear-cut hypercholesterolaemics. The results of this meta-analysis were criticised recently, since more recent studies appeared not to confirm the very powerful cholesterol-reducing effect of soya proteins ${ }^{(119)}$. However, when the initial cholesterolaemia is taken into account, it appears quite clearly that even the most recent studies are in line with the Anderson metaanalysis $^{(120)}$, since both in old and more recent studies, ranges of cholesterol responses of the groups of patients belonging to the same quartile are essentially identical. Old studies were based on severely hypercholesterolaemic individuals, whereas patients with cholesterolaemia in the very high range $(>3350 \mathrm{mg} / \mathrm{l})$ were not selected for treatment in recent studies. The major influence of baseline cholesterolaemia on the final effect of soya proteins was highlighted in an editorial ${ }^{(121)}$. A recent systematic metaanalysis of available randomised controlled studies mainly in subjects with moderate hypercholesterolaemia confirmed that the inclusion in the diet of a modest amount of soya protein $(25 \mathrm{~g})$ produces a highly significant reduction of total cholesterol and LDL-C, equivalent to about $6 \%$ LDL-C reduction ${ }^{(122)}$.

The cholesterol-reducing effect of soya proteins, potentially leading to a reduced cardiovascular risk, became the basis for the US Food and Drug Administration approval of the health claim for the role of soya protein consumption in coronary disease risk reduction ${ }^{(123)}$.

Rodent and in vitro studies have attempted to establish a link between the hypocholesterolaemic effects of soya and the activation/depression of liver LDL- ${ }^{(124,125)}$. Animals on cholesterol or cholic acid dietary regimens with casein have a dramatic down-regulation of liver LDL-R and this effect is reversed in the presence of soya proteins. Two studies have addressed the potential of soya protein preparations to increase LDL-R expression in human subjects. In the first ${ }^{(126)}$, familial hypercholesterolaemic patients were treated with animal protein or textured soya protein (with the addition of cholesterol to balance the two diets). Both plasma lipids and LDL degradation by circulating 
lympho-monocytes (used as mirror images of hepatocytes), were monitored. After the animal protein diet there were minimal changes in LDL-C levels or LDL-R activity, whereas during the soya protein diet, in addition to a marked LDL-C reduction, an increase of about 8 -fold in LDL degradation was observed. This study clearly suggests that some soya protein components are able to up-regulate LDLR-mediated LDL degradation, as was recently confirmed in individuals with lesser cholesterol elevations ${ }^{(127)}$.

A full understanding of the bioactive components in soya has become vital for the selection of the most appropriate forms of soya for treating hypercholesterolaemia, since the selection of the most efficacious products for treatment can only be made once the active component/s and their mechanism of action have been fully elucidated.

Initially isoflavones, i.e. the oestrogen-like components typically found predominantly in soya and only in very limited amounts in other grain legumes, were considered to have a main role in cholesterol reduction, based primarily on studies in monkeys ${ }^{(128)}$. A number of more recent reports have, however, definitely concluded that they make only a marginal contribution to the hypocholesterolaemic action in respect to the protein itself ${ }^{(119,129,130)}$. To confirm this, the soya products used in the first clinical studies were practically free of isoflavones as a consequence of processing $^{(131)}$.

Proteomics may be a powerful tool to achieve the objective of sorting out the bioactive components of the protein $^{(132)}$. The major storage proteins of soya are $7 \mathrm{~S}$ and $11 \mathrm{~S}$ globulins. From early studies the $7 \mathrm{~S}$ globulin appeared to be primarily responsible for the hypocholesterolaemic effects of soya protein preparations, whereas the $11 \mathrm{~S}$ component appeared essentially inactive ${ }^{(133,134)}$. Very recently a hypocholesterolaemic protein subcomponent has been suggested, i.e. by showing that the isolated $7 \mathrm{~S}$ globulin $\alpha^{\prime}$ subunit given to cholesterol-fed rats leads to a strong up-regulation of liver LDL-R activity as well as to dramatic plasma cholesterol and TAG reductions ${ }^{(135)}$.

Since proteins are hydrolysed in the gastrointestinal tract, it is quite likely that the hypocholesterolaemic soya components are peptides with less than fifteen amino acids, considering their potential to be absorbed. Many animalfeeding studies and two clinical trials ${ }^{(136,137)}$ have reported LDL-lowering effects of soya peptide preparations. In particular, Cho et al. disclosed $^{(138)}$ that the octa-peptide FVVNATSN, when added to HepG2 cells, leads to a significant LDL-R activation (about 2.5-fold). Preliminary findings seem to suggest that this subcomponent is absorbed intact.

Another interesting activity of these proteins, initially shown by Deibert et al. ${ }^{(139)}$, and then by Kohno et al. ${ }^{(140)}$ is that daily administration of four candies containing in total $5 \mathrm{~g}$ of $7 \mathrm{~S}$ globulin to moderately overweight Japanese individuals with hypertriacylglycerolaemia can reduce TAG by $14 \%$ and raise HDL-C by $5 \%$, while exerting a remarkable $6 \%$ reduction in the mean visceral fat area $(-10 \%$ in individuals with visceral fat area greater than $100 \mathrm{~cm}^{2}$ ). As foreseen, in neither of these studies ${ }^{(139,140)}$ in individuals with essentially normal cholesterolaemia was there evidence of any significant LDL-C reduction. Finally, beneficial effects of a soya protein-based diet were also recently described in Iranian women with the 'metabolic syndrome ${ }^{,(141)}$; these women had also reduced inflammatory markers after soya, as well as reduced insulin resistance ${ }^{(142)}$. The remarkable effectiveness of this very simple regimen thus reinforces the recommendation to increase the intake of soya proteins for cardiovascular protection.

\section{Other vegetable proteins}

Lupin seed is also considered very useful by the food industry, since it contains up to $35-40 \%$ protein. Two main species are cultivated, white lupin (Lupinus albus) and narrow-leaf lupin (L. angustifolius). Whole seeds of narrowleaf lupin showed a remarkable cholesterol-lowering effect in pigs fed a cholesterol-rich diet, compared with casein $^{(143)}$. The results of this study are probably due to the combined effects of several bioactive components, such as protein, soluble and insoluble fibres, phytosterols and possibly others. Other studies were focused only on the proteins. White lupin protein, evaluated in a rat model of hypercholesterolaemia ${ }^{(144)}$, indicated a substantial reduction of cholesterolaemia, with moderate changes of TAG and no effect on glucose. The decrease in plasma TAG concentrations appears to depend on a down-regulation of the liver SREBP-1c $\mathrm{c}^{(145)}$, a transcription factor that regulates the expression of lipogenic enzymes. White lupin protein was also evaluated in a rabbit model of focal soft plaque generated in the common carotid arteries ${ }^{(146)}$. In this model, carotid lesions are mostly constituted by extracellular lipids and macrophages, thus reflecting the main feature of the human arterial plaques, defined as unstable, frequently associated to acute ischaemic events ${ }^{(147)}$. Dietary treatment with lupin protein significantly reduced atherosclerosis development $v$. casein. White lupin protein isolate was also shown to significantly lower blood pressure in spontaneous diabetic and hypertensive rats ${ }^{(148)}$. This effect is possibly related to the high content of arginine, which may also lead to an increased NO production, and was confirmed in a preliminary clinical study ${ }^{(149)}$, based on a lupin beverage (daily lupin protein intake $=36 \mathrm{~g}$ ), indicating both reduced blood pressure as well as a clear cholesterol reduction in the hypercholesterolaemic subjects. A recent paper ${ }^{(150)}$ has shown that lupin kernel flour added to bread has also a positive effect on blood pressure: both the fibre and the protein may be responsible.

Other legumes investigated in the rat model of hypercholesterolaemia are pea ${ }^{(151,152)}$, chickpea ${ }^{(153)}$ and faba bean $^{(154)}$ : all induce a significant decrease of plasma LDL-C. A comparative study of diets containing four different legumes - baked beans, marrowfat peas, lentils and butter beans ${ }^{(155)}$ - showed effectiveness of them all, but baked beans and butter beans were the most potent. The hypocholesterolaemic activity was confirmed also in the pig model of cholesterolaemia: a study compared bean, pea, lentil and butter bean ${ }^{(156)}$, while another investigated only pea $^{(157)}$. There are also a few clinical studies available: most, including two by one of us, were based on common beans ${ }^{(158-161)}$ or mixed beans ${ }^{(162)}$, in some cases together with other bioactive components such as oat ${ }^{(163)}$; one was based instead on broad bean ${ }^{(164)}$. As already observed in the 
case of soya, the hypocholesterolaemic effect was evident ( -7 to $-9 \%$ total cholesterol) when the patients had an initial cholesterolaemia $>2400 \mathrm{mg} / \mathrm{l}$. In addition, very recently Winham \& Hutchins ${ }^{(165)}$ reported that baked bean consumption in moderately hypercholesterolaemic adults (mean LDL-C $1380 \mathrm{mg} / \mathrm{l}$ ) was associated with a reduction of LDL-cholesterolaemia $(-5.4 \%)$ with no changes in HDL-C levels.

\section{Fish protein}

Fish proteins have also attracted interest. Animal studies with fish proteins $v$. casein have suggested a potential hypocholesterolaemic activity ${ }^{(166,167)}$. Similarly to soya, fish proteins increased liver LDL-R and SREBP-2 mRNA concentrations and significantly reduced cholesterolaemia. Different from vegetable proteins, however, an HDL-C reduction was noted, albeit with an increased mRNA expression for apo AI. At present, however, little evidence has come from studies in human subjects, where, at best, fish intake has been linked to a hypotriacylglycerolaemic activity $^{(50)}$. A recent study ${ }^{(168)}$, however, has shown that a 6-week diet based on herrings, in comparison with a reference diet, significantly increases HDL-C and decreases TAG without any adverse effect on in vivo oxidation or serum antioxidants. Another potentially beneficial activity of fish proteins is on blood pressure, since angiotensinconverting enzyme (ACE) inhibitory peptides, well described mainly in milk and some plant proteins ${ }^{(169)}$, have been also detected in fish ${ }^{(170)}$ and could contribute to a reduced cardiovascular risk.

\section{Dark chocolate}

Cocoa is a flavonoid-rich food that has been recently investigated for its possible role in the prevention of $\mathrm{CVD}^{(171)}$. Cocoa flavonoids, catechins and procyanidins, can markedly decrease oxidant-induced peroxynitrite production in vitro and increase the NO synthase expression and NO-dependent vasodilation in rabbit aortic rings ${ }^{(172)}$. In healthy adults, drinking flavonoid-rich cocoa may improve NO-dependent vasorelaxation and flow-mediated dilation in the brachial arteries ${ }^{(173)}$. A controlled investigation in healthy volunteers showed that ingestion of flavanol-rich cocoa is associated with acute elevations of circulating NO species, enhanced flow-mediated response of conduit arteries and augmented microcirculation ${ }^{(174)}$. These findings suggested evaluation of dark chocolate, particularly rich in flavanols, $v$. flavanol-free white chocolate in patients with essential hypertension ${ }^{(175)}$. Administration of dark chocolate in essential hypertensives reduced ambulatory blood pressure by -11.9 (SD 7.7) $\mathrm{mmHg}$ ( $24 \mathrm{~h}$ systolic) and -8.5 (SD 5.0) $\mathrm{mmHg}(24 \mathrm{~h}$ diastolic), whereas $90 \mathrm{~g}$ white chocolate had no effects.

More recently both normocholesterolaemic and hypercholesterolaemic human subjects received graded doses of cocoa powder (from 13 to $26 \mathrm{~g} / \mathrm{d}$ ) high in polyphenols, or a placebo (low-polyphenol cocoa). There was a clear reduction of cholesterolaemia at both doses of the highpolyphenol cocoa as well as a significant rise of HDLcholesterolaemia (in addition to a marked reduction of circulating oxidised LDL) $v$. no activity for the placebo cocoa. These changes were highly significant in individuals with LDL-C $\geq 3.23 \mathrm{mmol} / 1(1300 \mathrm{mg} /)^{(176)}$. These findings confirm the earlier observation in the study in hypertensives where, after dark chocolate, there was an improvement of the homeostasis model assessment (HOMA) index and a small, statistically significant, reduction of serum LDL-C (from 3.4 to $3.0 \mathrm{mmol} / 1 ; P<0.05)^{(175)}$.

\section{Other functional ingredients}

\section{Red-yeast rice}

An extract of the Chinese red-yeast rice, Xuezhikang, contains a family of naturally occurring statins and is used as a supplement for CVD prevention in many countries. Two high-quality trials ${ }^{(177,178)}$ and two other studies ${ }^{(179,180)}$ have examined the effects of Chinese red-yeast rice. Doses of 1.2 to $2.4 \mathrm{~g} / \mathrm{d}$ reduced total cholesterol $(-19.7 \%)$, reduced LDL-C $(-19.8 \%)$, increased HDL-C $(+9.6 \%)$ and decreased TAG $(-17.6 \%)$. In addition, Zhao et al. ${ }^{(181)}$ recently reported a favourable outcome in the controlled China Coronary Secondary Prevention Study where a $1.20 \mathrm{~g}$ daily dose of Xuezhikang (comparable with $10 \mathrm{mg}$ lovastatin) reduced CHD events by $50.8 \%$ over 4 years in type 2 diabetics.

In a very recent randomised trial ${ }^{(182)}$, LDL-C level was significantly lower in the red-yeast rice group than in the placebo group at both week $12(P<0.001)$ and week 24 $(P=0.011)$. Significant treatment effects were also observed for total cholesterol at week $12(P<0.001)$ and week $24(P=0 \cdot 016)$. Levels of HDL-C, TAG, liver enzyme, creatine phosphokinase, body weight, and angina scores did not differ significantly between groups.

Occurrence of adverse events after Xuezhikang treatment is low, but appears to be of the same type as with statins, i.e. muscle complaints and others. It is mandatory that patients be aware of the possibility that side effects may occur due to the presence of a pharmacologically active molecule. Finally, it is important to observe that the commercialisation of products containing more than a trace of lovastatin is forbidden in the USA.

\section{Guggul gum}

Guggul gum or guggulipid, a resin from the mukul myrrh tree (Commiphora mukul), used for many medicinal purposes for millennia, has been tested for hypocholesterolaemic effects in at least four clinical trials ${ }^{(179)}$. Only two adequate randomised controlled trials are available ${ }^{(183,184)}$, with inconsistent findings. One additional controlled study ${ }^{(185)}$ was suitable for analysis. A total of 127 subjects used a variety of different extracts, with doses ranging from $50 \mathrm{mg} / \mathrm{d}$ to $6 \mathrm{~g} / \mathrm{d}$ : mean results after treatments from 3 to 8 weeks indicate a reduction of total cholesterol of $2.7 \%$, LDL-C of $2.0 \%$, HDL-C of $1.0 \%$ and TAG of $10.1 \%$. Rashes were noted in $15 \%$ of the high-dose guggulipidtreated subjects, $3 \%$ of the low-dose guggulipid group and none of the placebo group. Otherwise, guggulipid was well tolerated. 


\section{Fenugreek}

Seeds or leaves from fenugreek (Trigonella foenumgraecum) have also a long-standing recognition for diabetes and other metabolic diseases. Data from at least six clinical trials are available, but only one study ${ }^{(186)}$ appears to be a high-quality randomised controlled trial. It showed reduction of total cholesterol by $13.4 \%$, of LDL-C by $15.1 \%$ and of HDL-C by $2.7 \%$. Additional randomised controlled trials are necessary to establish the safety and hypocholesterolaemic efficacy of well-characterised preparations of fenugreek products.

\section{Evening primrose oil}

Evening primrose oil, rich in $\gamma$-linolenic acid, has been studied in rodents but limited data are available for human subjects $^{(187,188)}$; these data do not support a hypocholesterolaemic efficacy.

\section{Artichoke}

Similarly, artichoke has been examined in several clinical trials ${ }^{(189,190)}$, but the data are insufficient to make an assessment or recommendation at present.

\section{Cinnamon}

Cinnamon, a popular flavouring agent, has insulinenhancing activity, antioxidant properties and decreases serum lipid values in diabetic individuals ${ }^{(191,192)}$.

While these food ingredients are safe and widely used, their efficacy for favourably altering serum lipoprotein values require further controlled trials.

\section{Controversial topics}

Vitamin E

Whereas extensive epidemiological data and observational studies had indicated that vitamin $\mathrm{E}$ and other antioxidant supplements would have CVD-protective effects, disappointing results have been provided by recent randomised intervention trials $^{(193,194)}$. The Nutrition Committee of the American Heart Association no longer recommends vitamin E supplementation ${ }^{(42)}$. Vitamin E is, however, a generic term for eight naturally occurring lipophilic compounds, called tocopherols and tocotrienols. While tocopherols appear only to possess antioxidant properties, tocotrienol intake has been associated with anti-thrombotic, antiproliferative and hypocholesterolaemic effects ${ }^{(195)}$. An elegant development in the understanding of the mode of action of tocotrienols has come from recent in vitro work indicating enhanced Insig-dependent ubiquitination and degradation of 3-hydroxy-3-methyl-glutaryl (HMG)-CoA reductase by $\alpha$ - and $\gamma$ - (not by $\alpha$-) tocotrienols ${ }^{(196)}$. Enhanced degradation of HMG-CoA reductase can well explain the in vivo observation of increased LDL-R and HMG-CoA reductase mRNA following rice bran oil with a high content of $\gamma$-tocotrienol ${ }^{(197)}$. While these findings are potentially worthy of more in-depth evaluation, studies in human subjects with tocotrienols have provided conflicting results ${ }^{(195,198,199)}$.

\section{Garlic}

Garlic has been used as a food and medicine for centuries and many studies have examined its hypocholesterolaemic effects. From the extensive data available it seems that a daily consumption of one-half to one clove of garlic may decrease total cholesterol by 5-9\%; consumption of garlic extracts and dried garlic powder were similarly suggested to reduce cholesterolaemia by $2-6 \%^{(200-203)}$. In a recent trial $^{(204)}$, patients with moderate hypercholesterolaemia (LDL-C 1300-1900 mg/l) were randomised to: blended raw garlic $(4 \mathrm{~g})$, or an equivalent amount of powdered garlic supplement, garlic extract supplement or placebo over 6 months. Modest negative effects on LDL-C concentrations, i.e. ranging from $+32 \mathrm{mg} / 1$ to $+2 \mathrm{mg} / 1$ (placebo had the best effect) were observed.

A recent meta-analysis ${ }^{(205)}$ in this journal, including twenty-nine trials, was conducted in order to determine the impact of garlic on total cholesterol, TAG, as well as LDL-C and HDL-C. Garlic was found to significantly reduce total cholesterol $(-0.19 ; 95 \% \mathrm{CI}-0.33,-0.06 \mathrm{mmol} / \mathrm{l})$ and TAG $(-0.11 ; 95 \%$ CI $-0.19,-0.06 \mathrm{mmol} / \mathrm{l})$, but exhibited no significant effect on LDL-C or HDL-C. Future studies should be conducted evaluating the impact of adjunctive garlic therapy with fibrates or statins on TAG concentrations.

\section{Coffee}

Coffee consumption may possibly reduce the risk of myocardial infarction, but data are as yet inconclusive ${ }^{(206,207)}$. Very recent findings indicate that in individuals aged $\geq 65$ years high intakes of caffeinated beverages reduce relative CVD risk and heart disease mortality close to $50 \%$ in those taking four or more cups per $\mathrm{d}^{(208)}$. A doseresponse decrease and a similar protective effect were found for a daily caffeine intake of some milligrams; similar results were observed also in patients with type 2 diabetes $^{(209)}$.

Moderate or high intakes of unfiltered or instant coffee appear to be associated with serum LDL-C values about $5 \%$ higher $v$. baseline $e^{(207,210,211)}$. The active constituents of coffee apparently responsible for this effect are diterpenes, such as kahweol and cafestol; however, a major part of these diterpenes is retained by the paper filters used in making filtered coffee ${ }^{(211)}$. Cornelis and El-Sohemy tried to unravel the complex genetic factors favouring CHD or protecting from it ${ }^{(212,213)}$. Genetic susceptibility, in fact, may play a significant role: individuals with the apo E3/E3 genotype tend to have greater elevations in LDL-C in response to cafestol $v$. carriers of the other genotypes and, in addition, this may be the case of individuals with the apo A-I $83 \mathrm{CC}$ genotype $^{(212)}$.

\section{Tea}

Green tea consumption appears to protect from $\mathrm{CVD}^{(3,214-216)}$, but results are again not consistent. A recent meta-analysis reported that the incidence of myocardial infarction was $11 \%$ lower among individuals who consumed three cups of tea daily compared with nonusers, but this reduction was not statistically significant and 
there was large variability across studies ${ }^{(217)}$. While moderately high levels of tea consumption (more than four cups per d) may reduce CVD risk, the effects of tea consumption on serum lipoproteins are not clearly established $^{(218,219)}$. One small, placebo-controlled study reported a $3.8 \%$ reduction in serum total cholesterol and a $7.5 \%$ reduction in LDL-C after consumption of five servings of black tea daily by mildly hypercholesterolaemic adults; fasting serum TAG levels were slightly higher and HDL-C levels were unchanged ${ }^{(220)}$.

Very recent work has focused on the possible activity of green tea and its constituent epigallocatechin gallate on insulin secretion and the obesity-related insulin resistance syndrome. An enhanced insulin sensitivity has been observed in human subjects and laboratory animals. In diabetics Nagao et al. ${ }^{(221)}$ noted enhanced adiponectin levels and reduced waist circumference after a continuous ingestion of a catechin-rich green tea for 12 weeks; this was accompanied by reduced $\mathrm{HbA}_{1 \mathrm{c}}$ in patients treated with insulinotropic agents. A mechanistic study ${ }^{(22)}$ in an obese insulin-resistant dog model showed, instead, a rise of the insulin sensitivity index by $60 \%$ after green tea and a decrease of the TAG concentrations by $50 \%$, associated with an enhanced expression of PPAR $\gamma$, GLUT4, LPL and adiponectin in the adipose tissue and PPAR $\alpha$ and LPL in skeletal muscle. The potential therapeutic role of green tea in diabetes and hyperlipidaemias thus needs further evaluation.

\section{Policosanols}

Policosanols extracted from the Cuban sugar cane wax have been reported to substantially decrease serum LDL-C concentrations $^{(223)}$. Carefully controlled clinical trials from other countries have not confirmed these observations $^{(224-227)}$ and the effects of these compounds on serum lipids should be considered as unsubstantiated.

\section{Conclusion}

Diet and lifestyle goals for CVD prevention have received significant support from newer dietary recommendations, now with the potential to reduce serum total cholesterol and LDL-C by $30 \%$ or more, as well shown by the group of Jenkins with their 'portfolio diet', including fibres, plant proteins, nuts and phytosterols ${ }^{(228)}$. While an increase of carbohydrate consumption may lower cholesterol and LDL-C values, but also HDL concentrations, vegetable proteins can selectively reduce LDL-C in experimental animals and in humans with cholesterol elevations of genetic or non-genetic origin. Reduced fat intake is a hallmark in the prevention of arterial disease: recent studies underline the role of a high-monounsaturated (40\% of fat) diet that shows essentially no difference in benefit $v$. a standard low-fat $(20 \%)$ diet. These dietary approaches can also lead to a reduced blood pressure.

Numerous functional ingredients, for example, plant sterols and stanols, have a direct cholesterol-lowering activity, by mechanisms that may require further investigation. Novel polyphenols, for example, from dark chocolate, provide significant benefit on blood pressure as well as on the risk of thrombosis and certainly deserve deeper investigation.

Concerning the overall effects of $n-3$ fatty acids from fish or fish oil supplements, there is a general agreement, on the basis of outcomes in primary- and secondary-prevention studies, that increased consumption significantly reduces the rates of cardiac and especially of sudden death ${ }^{(229)}$.

Novel dietary approaches to cardiovascular prevention are thus of major significance in clinical research and practice. The apparent growing dislike of patients, particularly in primary prevention, for chronic drug intake will certainly lead to a wider use of these products in the cardiovascular field.

\section{Acknowledgements}

All authors contributed equally to the preparation of this paper.

There are no conflicts of interest, and no specific grant was received.

\section{References}

1. De Backer G, Ambrosioni E, Borch-Johnsen K, et al. (2003) European guidelines on cardiovascular disease and prevention in clinical practice. Atherosclerosis 171, 145-155.

2. Stampfer MJ, Hu FB, Manson JE, et al. (2000) Primary prevention of coronary heart disease in women through diet and lifestyle. N Engl J Med 343, 16-22.

3. Kris-Etherton PM, Etherton TD, Carlson J, et al. (2002) Recent discoveries in inclusive food-based approaches and dietary patterns for reduction in risk for cardiovascular disease. Curr Opin Lipidol 13, 397-407.

4. McCullough M, Feskanich D, Rimm E, et al. (2000) Adherence to the Dietary Guidelines for Americans and risk of major chronic disease in men. Am J Clin Nutr 72, $1223-1231$.

5. McCullough M, Feskanich D, Stampfer M, et al. (2000) Adherence to the Dietary Guidelines for Americans and risk of major chronic disease in women. Am J Clin Nutr 72, $1214-1222$.

6. Smith U (1994) Carbohydrates, fat, and insulin action. Am J Clin Nutr 59, 686S-689S.

7. Park EJ \& Hellerstein MK (2000) Carbohydrate-induced hypertriacylglycerolemia: historical perspective and review of biological mechanisms. Am J Clin Nutr 71, 412-433.

8. Anderson JW \& Ward K (1979) High-carbohydrate, highfiber diets for insulin-treated men with diabetes mellitus. Am J Clin Nutr 32, 2312-2321.

9. Anderson JW (2000) Dietary fiber prevents carbohydrateinduced hypertriglyceridemia. Curr Atheroscler Rep 2, 536-541.

10. Anderson JW, Garrity TF, Wood CL, et al. (1992) Prospective, randomized, controlled comparison of the effects of low-fat and low-fat plus high-fiber diets on serum lipid concentrations. Am J Clin Nutr 56, 887-894.

11. Frost G, Leeds AA, Doré CJ, et al. (1999) Glycaemic index as a determinant of serum HDL-cholesterol concentration. Lancet 353, 1045-1048.

12. Anderson JW, Randles KM, Kendall CW, et al. (2004) Carbohydrate and fiber recommendations for individuals with diabetes: a quantitative assessment and meta-analysis of the evidence. J Am Coll Nutr 23, 5-17. 
13. Shai I, Schwarzfuchs D, Henkin Y, et al. (2008) Weight loss with a low-carbohydrate, Mediterranean, or low-fat diet. $N$ Engl J Med 359, 229-241.

14. Jenkins D, Kendall C, McKeown-Eyssen G, et al. (2008) Effect of a low-glycemic index or a high-cereal fiber diet on type 2 diabetes: a randomized trial. JAMA 300, 2742-2753.

15. Erkkilä A \& Lichtenstein A (2006) Fiber and cardiovascular disease risk: how strong is the evidence? J Cardiovasc Nurs 21, 3-8.

16. Hall RS, Johnson SK, Baxter AL, et al. (2005) Lupin kernel fibre-enriched foods beneficially modify serum lipids in men. Eur J Clin Nutr 59, 325-333.

17. Hara H, Haga S, Aoyama Y, et al. (1999) Short-chain fatty acids suppress cholesterol synthesis in rat liver and intestine. J Nutr 129, 942-948.

18. Kirby RW, Anderson JW, Sieling B, et al. (1981) Oat-bran intake selectively lowers serum low-density lipoprotein cholesterol concentrations of hypercholesterolemic men. Am J Clin Nutr 34, 824-829.

19. Anderson JW, Zettwoch N, Feldman T, et al. (1988) Cholesterol-lowering effects of psyllium hydrophilic mucilloid for hypercholesterolemic men. Arch Intern Med 148, 292-296.

20. Anderson JW, Allgood LD, Lawrence A, et al. (2000) Cholesterol-lowering effects of psyllium intake adjunctive to diet therapy in men and women with hypercholesterolemia: meta-analysis of 8 controlled trials. Am J Clin Nutr 71, 472-479.

21. Ripsin CM, Keenan JM, Jacobs DRJ, et al. (1992) Oat products and lipid lowering. A meta-analysis. JAMA 267, 3317-3325.

22. Hasler CM (2002) Functional foods: benefits, concerns and challenges - a position paper from the American Council on Science and Health. J Nutr 132, 3772-3781.

23. Anderson JW (1995) Dietary fibre, complex carbohydrate and coronary artery disease. Can J Cardiol 11, Suppl. G, $55 \mathrm{G}-62 \mathrm{G}$.

24. Anderson JW, Davidson MH, Blonde L, et al. (2000) Longterm cholesterol-lowering effects of psyllium as an adjunct to diet therapy in the treatment of hypercholesterolemia. Am J Clin Nutr 71, 1433-1438.

25. Passi SJ, Manchanda SC, Suri S, et al. (2004) Lipid lowering effect of dietary fibre supplementation through food based approach. Asia Pac J Clin Nutr 28, Suppl. 13, S155.

26. Davidson MH, Dugan LD, Burns JH, et al. (1991) The hypocholesterolemic effects of $\beta$-glucan in oatmeal and oat bran. A dose-controlled study. JAMA 265, 1833-1839.

27. Anderson JW, Gilinsky NH, Deakins DA, et al. (1991) Lipid responses of hypercholesterolemic men to oat-bran and wheat-bran intake. Am J Clin Nutr 54, 678-683.

28. Gerhardt AL \& Gallo NB (1998) Full-fat rice bran and oat bran similarly reduce hypercholesterolemia in humans. J Nutr 128, 865-869.

29. Naumann E, van Rees AB, Onning G, et al. (2006) $\beta$ Glucan incorporated into a fruit drink effectively lowers serum LDL-cholesterol concentrations. Am J Clin Nutr 83, 601-605.

30. Keenan JM, Goulson M, Shamliyan T, et al. (2007) The effects of concentrated barley $\beta$-glucan on blood lipids in a population of hypercholesterolaemic men and women. $\mathrm{Br} J$ Nutr 97, 1162-1168.

31. Davidson MH \& Maki KC (1999) Effects of dietary inulin on serum lipids. J Nutr 129, 1474S-1477S.

32. Daubioul CA, Taper HS, De Wispelaere LD, et al. (2000) Dietary oligofructose lessens hepatic steatosis, but does not prevent hypertriglyceridemia in obese Zucker rats. $J$ Nutr 130, 1314-1319.
33. Delzenne NM \& Kok N (2001) Effects of fructans-type prebiotics on lipid metabolism. Am J Clin Nutr 73, 456S-458S.

34. Amori RE, Lau J \& Pittas AG (2007) Efficacy and safety of incretin therapy in type 2 diabetes: systematic review and meta-analysis. JAMA 298, 194-206.

35. Daubioul CA, Horsmans Y, Lambert P, et al. (2005) Effects of oligofructose on glucose and lipid metabolism in patients with nonalcoholic steatohepatitis: results of a pilot study. Eur J Clin Nutr 59, 723-726.

36. Misikangas M, Pajari A, Päivärinta E, et al. (2005) Promotion of adenoma growth by dietary inulin is associated with increase in cyclin D1 and decrease in adhesion proteins in Min/+ mice mucosa. J Nutr Biochem 16, 402-409.

37. Bjerregaard P \& Dyerberg J (1988) Mortality from ischaemic heart disease and cerebrovascular disease in Greenland. Int J Epidemiol 17, 514-519.

38. Bang HO, Dyerberg J \& Nielsen AB (1971) Plasma lipid and lipoprotein pattern in Greenlandic West-coast Eskimos. Lancet i, 1143-1145.

39. Visioli F, Risé P, Barassi MC, et al. (2003) Dietary intake of fish vs. formulations leads to higher plasma concentrations of $n-3$ fatty acids. Lipids 38, 415-418.

40. Elvevoll EO, Barstad H, Breimo ES, et al. (2006) Enhanced incorporation of $n-3$ fatty acids from fish compared with fish oils. Lipids 41, 1109-1114.

41. León H, Shibata M, Sivakumaran S, et al. (2008) Effect of fish oil on arrhythmias and mortality: systematic review. BMJ 337, a2931.

42. Lichtenstein AH, Appel LJ \& Brands M (2006) Diet and lifestyle recommendations revision 2006: a scientific statement from the American Heart Association Nutrition Committee. Circulation 114, 82-96.

43. Harris WS (1997) $n$-3 Fatty acids and serum lipoproteins: human studies. Am J Clin Nutr 65, Suppl. 5, 1645S-1654S.

44. Maki KC, Van Elswyk ME, McCarthy D, et al. (2005) Lipid responses to a dietary docosahexaenoic acid supplement in men and women with below average levels of high density lipoprotein cholesterol. J Am Coll Nutr 24, 189-199.

45. Theobald HE, Chowienczyk PJ, Whittall R, et al. (2004) LDL cholesterol-raising effect of low-dose docosahexaenoic acid in middle-aged men and women. Am J Clin Nutr 79, 558-563.

46. Bays H (2006) Clinical overview of Omacor: a concentrated formulation of omega-3 polyunsaturated fatty acids. Am J Cardiol 98, 71i-76i.

47. Kris-Etherton P \& Hill A (2008) n-3 Fatty acids: food or supplements? J Am Diet Assoc 108, 1125-1130.

48. Sirtori CR \& Galli C (2002) n-3 Fatty acids and diabetes. Biomed Pharmacother 56, 397-406.

49. Sirtori CR, Paoletti R, Mancini M, et al. (1997) n-3 Fatty acids do not lead to an increased diabetic risk in patients with hyperlipidemia and abnormal glucose tolerance. Italian Fish Oil Multicenter Study. Am J Clin Nutr 65, 1874-1881.

50. Sirtori CR, Crepaldi G, Manzato E, et al. (1998) One-year treatment with ethyl esters of $n-3$ fatty acids in patients with hypertriglyceridemia and glucose intolerance: reduced triglyceridemia, total cholesterol and increased HDL-C without glycemic alterations. Atherosclerosis 137, 419-427.

51. Dubey P \& Cheema SK (2006) Molecular mechanisms involved in the regulation of lipid and lipoprotein metabolism by fish oil. Fut Lipidol 1, 559-568. 
52. Mooradian AD, Haas MJ \& Wong NC (2006) The effect of select nutrients on serum high-density lipoprotein cholesterol and apolipoprotein A-I levels. Endocr Rev 27, 2-16.

53. Borghi C \& Cicero A (2006) Recent evidence of the role of omega-3 polyunsaturated fatty acids on blood pressure control and hypertension-related complications. Fut Lipidol 1, 569-577.

54. Yokoyama M, Origasa H, Matsuzaki M, et al. (2007) Effects of eicosapentaenoic acid on major coronary events in hypercholesterolaemic patients (JELIS): a randomised open-label, blinded endpoint analysis. Lancet 369, 1090-1098.

55. Visioli F, Risè P, Plasmati E, et al. (2000) Very low intakes of $n-3$ fatty acids incorporated into bovine milk reduce plasma triacylglycerol and increase HDL-cholesterol concentrations in healthy subjects. Pharmacol Res 41, 571-576.

56. Carrero JJ, Baró L, Fonollá J, et al. (2004) Cardiovascular effects of milk enriched with omega-3 polyunsaturated fatty acids, oleic acid, folic acid, and vitamins $\mathrm{E}$ and $\mathrm{B}_{6}$ in volunteers with mild hyperlipidemia. Nutrition 20, 521-527.

57. Mozaffarian D \& Rimm EB (2006) Fish intake, contaminants, and human health: evaluating the risks and the benefits. JAMA 296, 1885-1899.

58. Marangoni F, Colombo C, Martiello A, et al. (2007) Levels of the $n-3$ fatty acid eicosapentaenoic acid in addition to those of $\alpha$ linolenic acid are significantly raised in blood lipids by the intake of four walnuts a day in humans. Nutr Metab Cardiovasc Dis 17, 457-461.

59. Burdge $\mathrm{G}$ (2004) $\alpha$-Linolenic acid metabolism in men and women: nutritional and biological implications. Curr Opin Clin Nutr Metab Care 7, 137-144.

60. von Schacky C (2003) The role of omega-3 fatty acids in cardiovascular disease. Curr Atheroscler Rep 5, 139-145.

61. Djoussé L, Arnett DK, Carr JJ, et al. (2005) Dietary linolenic acid is inversely associated with calcified atherosclerotic plaque in the coronary arteries: the National Heart, Lung, and Blood Institute Family Heart Study. Circulation 111, 2921-2926.

62. Zhao G, Etherton TD, Martin KR, et al. (2004) Dietary $\alpha$-linolenic acid reduces inflammatory and lipid cardiovascular risk factors in hypercholesterolemic men and women. J Nutr 134, 2991-2997.

63. Rallidis LS, Paschos G, Papaioannou ML, et al. (2004) The effect of diet enriched with $\alpha$-linolenic acid on soluble cellular adhesion molecules in dyslipidaemic patients. Atherosclerosis 174, 127-132.

64. Sanderson P, Finnegan Y, Williams C, et al. (2002) UK Food Standards Agency $\alpha$-linolenic acid workshop report. $\mathrm{Br} J$ Nutr 88, 573-579.

65. Wendland E, Farmer A, Glasziou P, et al. (2006) Effect of $\alpha$ linolenic acid on cardiovascular risk markers: a systematic review. Heart 92, 166-169.

66. Harris WS (2005) $\alpha$-Linolenic acid: a gift from the land? Circulation 111, 2872-2874.

67. Davis HRJ, Zhu LJ, Hoos LM, et al. (2004) Niemann-Pick $\mathrm{C} 1$ like 1 (NPC1L1) is the intestinal phytosterol and cholesterol transporter and a key modulator of whole-body cholesterol homeostasis. J Biol Chem 279, 33586-33592.

68. Field FJ, Born E \& Mathur SN (2004) Stanol esters decrease plasma cholesterol independently of intestinal ABC sterol transporters and Niemann-Pick C1-like 1 protein gene expression. J Lipid Res 45, 2252-2259.

69. Miettinen TA, Puska P, Gylling H, et al. (1995) Reduction of serum cholesterol with sitostanol-ester margarine in a mildly hypercholesterolemic population. $N$ Engl J Med 333, 1308-1312.

70. Gylling H, Radhakrishnan R \& Miettinen TA (1997) Reduction of serum cholesterol in postmenopausal women with previous myocardial infarction and cholesterol malabsorption induced by dietary sitostanol ester margarine: women and dietary sitostanol. Circulation 96, 4226-4231.

71. Hallikainen MA \& Uusitupa MI (1999) Effects of 2 low-fat stanol ester-containing margarines on serum cholesterol concentrations as part of a low-fat diet in hypercholesterolemic subjects. Am J Clin Nutr 69, 403-410.

72. Davidson MH, Maki KC, Umporowicz DM, et al. (2001) Safety and tolerability of esterified phytosterols administered in reduced-fat spread and salad dressing to healthy adult men and women. J Am Coll Nutr 20, 307-319.

73. Maki KC, Davidson MH, Umporowicz DM, et al. (2001) Lipid responses to plant-sterol-enriched reduced-fat spreads incorporated into a National Cholesterol Education Program Step I diet. Am J Clin Nutr 74, 33-43.

74. Neil HA, Meijer GW \& Roe LS (2001) Randomised controlled trial of use by hypercholesterolaemic patients of a vegetable oil sterol-enriched fat spread. Atherosclerosis 156, 329-337.

75. Ntanios FY \& Duchateau GS (2002) A healthy diet rich in carotenoids is effective in maintaining normal blood carotenoid levels during the daily use of plant sterolenriched spreads. Int J Vitam Nutr Res 72, 32-39.

76. Matvienko OA, Lewis DS, Swanson M, et al. (2002) A single daily dose of soybean phytosterols in ground beef decreases serum total cholesterol and LDL cholesterol in young, mildly hypercholesterolemic men. Am J Clin Nutr 76, 57-64.

77. Winter J (2005) The phytosterol phenomenon. Functional Foods and Nutraceuticals, pp. 24-30, 1 April.

78. Cater NB, Garcia-Garcia AB, Vega GL, et al. (2005) Responsiveness of plasma lipids and lipoproteins to plant stanol esters. Am J Cardiol 96, 23D-28D.

79. O’Neill FH, Brynes A, Mandeno R, et al. (2004) Comparison of the effects of dietary plant sterol and stanol esters on lipid metabolism. Nutr Metab Cardiovasc Dis 14, $133-142$.

80. Vanstone CA, Raeini-Sarjaz M, Parsons WE, et al. (2002) Unesterified plant sterols and stanols lower LDL-cholesterol concentrations equivalently in hypercholesterolemic persons. Am J Clin Nutr 76, 1272-1278.

81. Richelle M, Enslen M, Hager C, et al. (2004) Both free and esterified plant sterols reduce cholesterol absorption and the bioavailability of $\beta$-carotene and $\alpha$-tocopherol in normocholesterolemic humans. Am J Clin Nutr 80, 171-177.

82. Spilburg CA, Goldberg AC, McGill JB, et al. (2003) Fatfree foods supplemented with soy stanol-lecithin powder reduce cholesterol absorption and LDL cholesterol. J Am Diet Assoc 103, 577-581.

83. Salo P \& Wester I (2005) Low-fat formulations of plant stanols and sterols. Am J Cardiol 96, 51D-54D.

84. Clifton P (2002) Plant sterol and stanols - comparison and contrasts Sterols versus stanols in cholesterol-lowering: is there a difference? Atheroscler Suppl 3, 5-9.

85. Hallikainen MA, Sarkkinen ES \& Uusitupa MI (2000) Plant stanol esters affect serum cholesterol concentrations of hypercholesterolemic men and women in a dose-dependent manner. J Nutr 130, 767-776.

86. Chan Y, Demonty I, Pelled D, et al. (2007) Olive oil containing olive oil fatty acid esters of plant sterols and dietary diacylglycerol reduces low-density lipoprotein 
cholesterol and decreases the tendency for peroxidation in hypercholesterolaemic subjects. Br J Nutr 98, 563-570.

87. Demonty I, Ras R, van der Knaap H, et al. (2009) Continuous dose-response relationship of the LDL-cholesterol-lowering effect of phytosterol intake. J Nutr 139, $271-284$.

88. AbuMweis SS, Barake R \& Jones P (2008) Plant sterols/stanols as cholesterol lowering agents: a metaanalysis of randomized controlled trials. Food Nutr Res $\mathbf{5 2}$ (epublication 18 August 2008).

89. de Jongh S, Vissers MN, Rol P, et al. (2003) Plant sterols lower LDL cholesterol without improving endothelial function in prepubertal children with familial hypercholesterolaemia. J Inherit Metab Dis 26, 343-351.

90. Anonymous (2001) Executive Summary of The Third Report of The National Cholesterol Education Program (NCEP) Expert Panel on Detection Expert Panel on Detection, Evaluation, and Treatment of High Blood Cholesterol In Adults (Adult Treatment Panel III). JAMA 285, 2486-2497.

91. Wolfs M, de Jong N, Ocké MC, et al. (2006) Effectiveness of customary use of phytosterol/stanol-enriched margarines on blood cholesterol lowering. Food Chem Toxicol 44, $1682-1688$

92. Shrestha S, Volek JS, Udani J, et al. (2006) A combination therapy including psyllium and plant sterols lowers LDL cholesterol by modifying lipoprotein metabolism in hypercholesterolemic individuals. J Nutr 136, 2492-2497.

93. Theuwissen E \& Mensink RP (2007) Simultaneous intake of $\beta$-glucan and plant stanol esters affects lipid metabolism in slightly hypercholesterolemic subjects. J Nutr 137, 583-588.

94. Devaraj S, Autret BC \& Jialal I (2006) Reduced-calorie orange juice beverage with plant sterols lowers C-reactive protein concentrations and improves the lipid profile in human volunteers. Am J Clin Nutr 84, 756-761.

95. Micallef M \& Garg M (2008) The lipid-lowering effects of phytosterols and (n-3) polyunsaturated fatty acids are synergistic and complementary in hyperlipidemic men and women. J Nutr 138, 1086-1090.

96. Coates AM \& Howe PR (2007) Edible nuts and metabolic health. Curr Opin Lipidol 18, 25-30.

97. Kris-Etherton PM, Zhao G, Binkoski AE, et al. (2001) The effects of nuts on coronary heart disease risk. Nutr Rev 59, $103-111$.

98. Mukuddem-Petersen J, Oosthuizen W \& Jerling JC (2005) A systematic review of the effects of nuts on blood lipid profiles in humans. J Nutr 135, 2082-2089.

99. Albert CM, Gaziano JM, Willett WC, et al. (2002) Nut consumption and decreased risk of sudden cardiac death in the Physicians' Health Study. Arch Intern Med 162, $1382-1387$.

100. Feldman EB (2002) The scientific evidence for a beneficial health relationship between walnuts and coronary heart disease. J Nutr 132, 1062S-1101S.

101. Alasalvar C, Shahidi F \& Cadwallader KR (2003) Comparison of natural and roasted Turkish tombul hazelnut (Corylus avellana L.) volatiles and flavor by DHA/GC/MS and descriptive sensory analysis. J Agric Food Chem 51, 5067-5072.

102. Mercanligil SM, Arslan P, Alasalvar C, et al. (2007) Effects of hazelnut-enriched diet on plasma cholesterol and lipoprotein profiles in hypercholesterolemic adult men. Eur J Clin Nutr 61, 212-220.

103. Josse AR, Kendall CW, Augustin LS, et al. (2007) Almonds and postprandial glycemia - a dose-response study. Metabolism 56, 400-404.
104. Garg ML, Blake RJ \& Wills RB (2003) Macadamia nut consumption lowers plasma total and LDL cholesterol levels in hypercholesterolemic men. J Nutr 133, 1060-1063.

105. Food and Drug Administration (2003) Qualified Health Claims: Letter of Enforcement Discretion - Nuts and Coronary Heart Disease. docket no. 02P-0505. Washington, DC: FDA.

106. Willett WC (2004) Eat, Drink and be Healthy. The Harvard Medical School Guide to Healthy Eating. New York: Simon and Schuster.

107. Kim DN, Lee KT, Reiner JM, et al. (1980) Increased steroid excretion in swine fed high-fat, high-cholesterol diet with soy protein. Exp Mol Pathol 33, 25-35.

108. Terpstra AH, Woodward CJ, West CE, et al. (1982) A longitudinal cross-over study of serum cholesterol and lipoproteins in rabbits fed on semi-purified diets containing either casein or soya-bean protein. Br J Nutr 47, 213-221.

109. Sirtori CR, Agradi E, Conti F, et al. (1977) Soybean-protein diet in the treatment of type-II hyperlipoproteinaemia. Lancet i, 275-277.

110. Descovich GC, Ceredi C, Gaddi A, et al. (1980) Multicentre study of soybean protein diet for outpatient hypercholesterolaemic patients. Lancet ii, 709-712.

111. Gaddi A, Descovich GC, Noseda G, et al. (1987) Hypercholesterolaemia treated by soybean protein diet. Arch Dis Child 62, 274-278.

112. Sirtori CR, Lovati MR \& Manzoni C (1998) Reduction of serum cholesterol by soybean proteins: clinical experience and potential molecular mechanisms. Nutr Metab Cardiovasc Dis 8, 334-340.

113. Bakhit RM, Klein BP, Essex-Sorlie D, et al. (1994) Intake of $25 \mathrm{~g}$ of soybean protein with or without soybean fiber alters plasma lipids in men with elevated cholesterol concentrations. J Nutr 124, 213-222.

114. Burslem J, Schonfeld G, Howald MA, et al. (1978) Plasma apoprotein and lipoprotein lipid levels in vegetarians. Metabolism 27, 711-719.

115. Zhang X, Shu XO, Gao YT, et al. (2003) Soy food consumption is associated with lower risk of coronary heart disease in Chinese women. J Nutr 133, 2874-2878.

116. Nagata C, Takatsuka N, Kurisu Y, et al. (1998) Decreased serum total cholesterol concentration is associated with high intake of soy products in Japanese men and women. $J$ Nutr 128, 209-213.

117. Halton TL, Willett WC, Liu S, et al. (2006) Lowcarbohydrate-diet score and the risk of coronary heart disease in women. $N$ Engl J Med 355, 1991-2002.

118. Anderson JW, Johnstone BM \& Cook-Newell ME (1995) Meta-analysis of the effects of soy protein intake on serum lipids. $N$ Engl J Med 333, 276-282.

119. Sacks FM, Lichtenstein A, Van Horn L, et al. (2006) Soy protein, isoflavones, and cardiovascular health: an American Heart Association Science Advisory for professionals from the Nutrition Committee. Circulation 113, 1034-1044.

120. Sirtori CR, Eberini I \& Arnoldi A (2007) Hypocholesterolaemic effects of soya proteins: results of recent studies are predictable from the Anderson meta-analysis data. Br J Nutr 97, 816-822.

121. Steinberg FM (2007) Soybeans or soymilk: does it make a difference for cardiovascular protection? Does it even matter? Am J Clin Nutr 85, 927-928.

122. Harland J \& Haffner T (2008) Systematic review, metaanalysis and regression of randomised controlled trials reporting an association between an intake of circa $25 \mathrm{~g}$ soya protein per day and blood cholesterol. Atherosclerosis 200, 13-27. 
123. Food and Drug Administration (1999) Food labeling health claims: soybean protein and coronary heart disease. Final rule. In Federal Register, vol. 64, no. 206, pp. 57699-57733. Washington, DC: Department of Health and Human Services.

124. Sirtori CR, Galli G, Lovati MR, et al. (1984) Effects of dietary proteins on the regulation of liver lipoprotein receptors in rats. J Nutr 114, 1493-1500.

125. Lovati MR, Manzoni C, Gianazza E, et al. (2000) Soy protein peptides regulate cholesterol homeostasis in Hep G2 cells. J Nutr 130, 2543-2549.

126. Lovati MR, Manzoni C, Canavesi A, et al. (1987) Soybean protein diet increases low density lipoprotein receptor activity in mononuclear cells from hypercholesterolemic patients. J Clin Invest 80, 1498-1502.

127. Baum JA, Teng H, Erdman JWJ, et al. (1998) Long-term intake of soy protein improves blood lipid profiles and increases mononuclear cell low-density-lipoprotein receptor messenger RNA in hypercholesterolemic, postmenopausal women. Am J Clin Nutr 68, 545-551.

128. Anthony MS, Clarkson TB, Hughes CL Jr, et al. (1996) Soybean isoflavones improve cardiovascular risk factors without affecting the reproductive system of peripubertal rhesus monkeys. J Nutr 126, 43-50.

129. Greaves KA, Parks JS, Williams JK, et al. (1999) Intact dietary soy protein, but not adding an isoflavone-rich soy extract to casein, improves plasma lipids in ovariectomized cynomolgus monkeys. J Nutr 129, 1585-1592.

130. Sirtori CR, Arnoldi A \& Johnson SK (2005) Phytoestrogens: end of a tale? Ann Med 37, 423-438.

131. Sirtori CR, Gianazza E, Manzoni C, et al. (1997) Role of isoflavones in the cholesterol reduction by soy proteins in the clinic. Am J Clin Nutr 65, 166-167.

132. Gianazza E, Eberini I, Arnoldi A, et al. (2003) A proteomic investigation of isolated soy proteins with variable effects in experimental and clinical studies. J Nutr 133, 9-14.

133. Lovati MR, Manzoni C, Corsini A, et al. (1996) 7S globulin from soybean is metabolized in human cell cultures by a specific uptake and degradation system. J Nutr 126, 2831-2842.

134. Lovati MR, Manzoni C, Corsini A, et al. (1992) Low density lipoprotein receptor activity is modulated by soybean globulins in cell culture. J Nutr 122, 1971-1978.

135. Duranti M, Lovati MR, Dani V, et al. (2004) The $\alpha^{\prime}$ subunit from soybean 7S globulin lowers plasma lipids and upregulates liver $\beta$-VLDL receptors in rats fed a hypercholesterolemic diet. J Nutr 134, 1334-1339.

136. Wang MF, Yamamoto S, Chung HM, et al. (1995) Antihypercholesterolemic effect of undigested fraction of soybean protein in young female volunteers. $J$ Nutr Sci Vitaminol (Tokyo) 41, 187-195.

137. Hori G, Wang MF, Chan YC, et al. (2001) Soy protein hydrolyzate with bound phospholipids reduces serum cholesterol levels in hypercholesterolemic adult male volunteers. Biosci Biotechnol Biochem 65, 72-78.

138. Cho S, Juillerat M \& Lee C (2008) Identification of LDLreceptor transcription stimulating peptides from soybean hydrolysate in human hepatocytes. J Agric Food Chem 56, 4372-4376.

139. Deibert P, König D, Schmidt-Trucksaess A, et al. (2004) Weight loss without losing muscle mass in pre-obese and obese subjects induced by a high-soy-protein diet. Int $J$ Obes Relat Metab Disord 28, 1349-1352.

140. Kohno M, Hirotsuka M, Kito M, et al. (2006) Decreases in serum triacylglycerol and visceral fat mediated by dietary soybean $\beta$-conglycinin. J Atheroscler Thromb 13, 247-255.
141. Azadbakht L, Kimiagar M, Mehrabi Y, et al. (2007) Soy inclusion in the diet improves features of the metabolic syndrome: a randomized crossover study in postmenopausal women. Am J Clin Nutr 85, 735-741.

142. Azadbakht L, Kimiagar M, Mehrabi Y, et al. (2007) Soy consumption, markers of inflammation, and endothelial function: a cross-over study in postmenopausal women with the metabolic syndrome. Diabetes Care 30, 967-973.

143. Martins JM, Riottot M, de Abreu MC, et al. (2005) Cholesterol-lowering effects of dietary blue lupin (Lupinus angustifolius L.) in intact and ileorectal anastomosed pigs. J Lipid Res 46, 1539-1547.

144. Sirtori CR, Lovati MR, Manzoni C, et al. (2004) Proteins of white lupin seed, a naturally isoflavone-poor legume, reduce cholesterolemia in rats and increase LDL receptor activity in HepG2 cells. J Nutr 134, 18-23.

145. Spielmann J, Shukla A, Brandsch C, et al. (2007) Dietary lupin protein lowers triglyceride concentrations in liver and plasma in rats by reducing hepatic gene expression of sterol regulatory element-binding protein-1c. Ann Nutr Metab 51, 387-392.

146. Marchesi M, Parolini C, Diani E, et al. (2008) Hypolipidemic and anti-atherosclerotic effects of lupin proteins in a rabbit model. Br J Nutr 100, 707-710.

147. Chiesa G, Di Mario C, Colombo N, et al. (2001) Development of a lipid-rich, soft plaque in rabbits, monitored by histology and intravascular ultrasound. Atherosclerosis 156, 277-287.

148. Pilvi TK, Jauhiainen T, Cheng ZJ, et al. (2006) Lupin protein attenuates the development of hypertension and normalises the vascular function of $\mathrm{NaCl}$-loaded GotoKakizaki rats. J Physiol Pharmacol 57, 167-176.

149. Nowicka G, Klosiewicz-Latoszek L, Sirtori CR, et al. (2006) Lupin proteins in the treatment of hypercholesterolemia. Atheroscler Suppl 7, 477.

150. Lee Y, Mori T, Puddey I, et al. (2009) Effects of lupin kernel flour-enriched bread on blood pressure: a controlled intervention study. Am J Clin Nutr 89, 766-772.

151. Lasekan JB, Gueth L \& Khan S (1995) Influence of dietary golden pea protein versus casein on plasma and hepatic lipids in rats. Nutr Res 15, 71-84.

152. Alonso R, Grant G \& Marzo F (2001) Thermal treatment improves nutritional quality of pea seeds (Pisum sativum L.) without reducing their hypocholesterolemic properties. Nutr Res 21, 1067-1077.

153. Zulet MA, Macarulla MT, Portillo MP, et al. (1999) Lipid and glucose utilization in hypercholesterolemic rats fed a diet containing heated chickpea (Cicer aretinum L.): a potential functional food. Int J Vitam Nutr Res 69, 403-411.

154. Macarulla MT, Medina C, De Diego MA, et al. (2001) Effects of the whole seed and a protein isolate of faba bean (Vicia faba) on the cholesterol metabolism of hypercholesterolaemic rats. Br J Nutr 85, 607-614.

155. Dabai FD, Walker AF, Sambrook IE, et al. (1996) Comparative effects on blood lipids and faecal steroids of five legume species incorporated into a semi-purified, hypercholesterolaemic rat diet. Br J Nutr 75, 557-571.

156. Kingman SM, Walker AF, Low AG, et al. (1993) Comparative effects of four legume species on plasma lipids and faecal steroid excretion in hypercholesterolaemic pigs. Br J Nutr 69, 409-421.

157. Martins JM, Riottot M, de Abreu MC, et al. (2004) Dietary raw peas (Pisum sativum L.) reduce plasma total and LDL cholesterol and hepatic esterified cholesterol in intact and ileorectal anastomosed pigs fed cholesterol-rich diets. $J$ Nutr 134, 3305-3312. 
158. Anderson JW, Story L, Sieling B, et al. (1984) Hypocholesterolemic effects of oat-bran or bean intake for hypercholesterolemic men. Am J Clin Nutr 40, 1146-1155.

159. Anderson JW, Gustafson NJ, Spencer DB, et al. (1990) Serum lipid response of hypercholesterolemic men to single and divided doses of canned beans. Am J Clin Nutr 51, 1013-1019.

160. Cobiac L, McArthur R \& Nestel PJ (1990) Can eating baked beans lower plasma cholesterol? Eur J Clin Nutr 44, 819-822.

161. Oosthuizen W, Scholtz CS, Vorster HH, et al. (2000) Extruded dry beans and serum lipoprotein and plasma haemostatic factors in hyperlipidaemic men. Eur J Clin Nutr 54, 373-379.

162. Jenkins DJ, Wong GS, Patten R, et al. (1983) Leguminous seeds in the dietary management of hyperlipidemia. Am J Clin Nutr 38, 567-573.

163. Mackay S \& Ball MJ (1992) Do beans and oat bran add to the effectiveness of a low-fat diet? Eur J Clin Nutr 46, 641-648.

164. Frühbeck G, Monreal I \& Santidrián S (1997) Hormonal implications of the hypocholesterolemic effect of intake of field beans (Vicia faba L.) by young men with hypercholesterolemia. Am J Clin Nutr 66, 1452-1460.

165. Winham DM \& Hutchins AM (2007) Aked bean consumption reduces serum cholesterol in hypercholesterolemic adults. Nutr Res 27, 380-386.

166. Zhang X \& Beynen AC (1993) Influence of dietary fish proteins on plasma and liver cholesterol concentrations in rats. Br J Nutr 69, 767-777.

167. Shukla A, Bettzieche A, Hirche F, et al. (2006) Dietary fish protein alters blood lipid concentrations and hepatic genes involved in cholesterol homeostasis in the rat model. $\mathrm{Br} J$ Nutr 96, 674-682.

168. Lindqvist H, Langkilde A, Undeland I, et al. (2009) Herring (Clupea harengus) intake influences lipoproteins but not inflammatory and oxidation markers in overweight men. $\mathrm{Br}$ J Nutr 101, 383-390.

169. Sirtori C, Galli C, Anderson J, et al. (2009) Nutritional and nutraceutical approaches to dyslipidemia and atherosclerosis prevention: focus on dietary proteins. Atherosclerosis 203, 8-17.

170. Vercruysse L, Van Camp J \& Smagghe G (2005) ACE inhibitory peptides derived from enzymatic hydrolysates of animal muscle protein: a review. J Agric Food Chem 53, 8106-8115.

171. Ding EL, Hutfless SM, Ding X, et al. (2006) Chocolate and prevention of cardiovascular disease: a systematic review. Nutr Metab (Lond) 3, 2.

172. Kurosawa T, Itoh F, Nozaki A, et al. (2005) Suppressive effect of cocoa powder on atherosclerosis in Kurosawa and Kusanagi-hypercholesterolemic rabbits. $J$ Atheroscler Thromb 12, 20-28.

173. Grassi D, Necozione S, Lippi C, et al. (2005) Cocoa reduces blood pressure and insulin resistance and improves endothelium-dependent vasodilation in hypertensives. Hypertension 46, 398-405.

174. Schroeter H, Heiss C, Balzer J, et al. (2006) (-)-Epicatechin mediates beneficial effects of flavanol-rich cocoa on vascular function in humans. Proc Natl Acad Sci USA 103, 1024-1029.

175. Grassi D, Lippi C, Necozione S, et al. (2005) Short-term administration of dark chocolate is followed by a significant increase in insulin sensitivity and a decrease in blood pressure in healthy persons. Am J Clin Nutr 81, 611-614.
176. Baba S, Natsume M, Yasuda A, et al. (2007) Plasma LDL and HDL cholesterol and oxidized LDL concentrations are altered in normo- and hypercholesterolemic humans after intake of different levels of cocoa powder. J Nutr 137, 1436-1441.

177. Heber D, Yip I, Ashley J, et al. (1999) Cholesterol-lowering effects of a proprietary Chinese red-yeast-rice dietary supplement. Am J Clin Nutr 69, 231-236.

178. Zhao SP, Liu L, Cheng YC, et al. (2004) Xuezhikang, an extract of cholestin, protects endothelial function through antiinflammatory and lipid-lowering mechanisms in patients with coronary heart disease. Circulation 110, 915-920.

179. Coon J \& Ernst E (2003) Herbs for serum cholesterol reduction. J Fam Pract 52, 468-478.

180. Keithley JK, Swanson B, Sha BE, et al. (2002) A pilot study of the safety and efficacy of cholestin in treating HIVrelated dyslipidemia. Nutrition 18, 201-204.

181. Zhao S, Lu Z, Du B, et al. (2007) Xuezhikang, an extract of cholestin, reduces cardiovascular events in type 2 diabetes patients with coronary heart disease: subgroup analysis of patients with type 2 diabetes from China Coronary Secondary Prevention Study (CCSPS). J Cardiovasc Pharm 49, 81-84.

182. Becker D, Gordon R, Halbert S, et al. (2009) Red yeast rice for dyslipidemia in statin-intolerant patients: a randomized trial. Ann Intern Med 150, 830-839.

183. Szapary PO, Wolfe ML, Bloedon LT, et al. (2003) Guggulipid for the treatment of hypercholesterolemia: a randomized controlled trial. JAMA 290, 765-772.

184. Singh RB, Niaz MA \& Ghosh S (1994) Hypolipidemic and antioxidant effects of Commiphora mukul as an adjunct to dietary therapy in patients with hypercholesterolemia. Cardiovasc Drugs Ther 8, 659-664.

185. Kuppurajan K, Rajagopalan SS, Rao TK, et al. (1978) Effect of guggulu (Commiphora mukul-Engl.) on serum lipids in obese, hypercholesterolemic and hyperlipemic cases. J Assoc Physicians India 26, 367-373.

186. Singh RB, Niaz MA, Rastogi V, et al. (1998) Hypolipidemic and antioxidant effects of fenugreek seed and triphala as adjuncts to dietary therapy in patients with mild to moderate hypercholesterolemia. Perfusion 11, 124-130.

187. Ishikawa T, Fujiyama Y, Igarashi O, et al. (1989) Effects of $\gamma$-linolenic acid on plasma lipoproteins and apolipoproteins. Atherosclerosis 75, 95-104.

188. Boberg M, Vessby B \& Selinus I (1986) Effects of dietary supplementation with $n-6$ and $n$-3 long-chain polyunsaturated fatty acids on serum lipoproteins and platelet function in hypertriglyceridaemic patients. Acta Med Scand 220, $153-160$.

189. Englisch W, Beckers C, Unkauf M, et al. (2000) Efficacy of artichoke dry extract in patients with hyperlipoproteinemia. Arzneimittelforschung 50, 260-265.

190. Pittler MH, Thompson CO \& Ernst E (2002) Artichoke leaf extract for treating hypercholesterolaemia. The Cochrane Database of Systematic Reviews 2002, issue 3, CD003335. http://www.mrw.interscience.wiley.com/cochrane/clsysrev/ articles/CD003335/frame.html

191. Anderson RA, Broadhurst CL, Polansky MM, et al. (2004) Isolation and characterization of polyphenol type-A polymers from cinnamon with insulin-like biological activity. J Agric Food Chem 52, 65-70.

192. Khan A, Safdar M, Ali Khan MM, et al. (2003) Cinnamon improves glucose and lipids of people with type 2 diabetes. Diabetes Care 26, 3215-3218. 
193. Brown BG, Cheung MC, Lee AC, et al. (2002) Antioxidant vitamins and lipid therapy: end of a long romance? Arterioscler Thromb Vasc Biol 22, 1535-1546.

194. Knekt P, Ritz J, Pereira MA, et al. (2004) Antioxidant vitamins and coronary heart disease risk: a pooled analysis of 9 cohorts. Am J Clin Nutr 80, 1508-1520.

195. Baliarsingh S, Beg ZH \& Ahmad J (2005) The therapeutic impacts of tocotrienols in type 2 diabetic patients with hyperlipidemia. Atherosclerosis 182, 367-374.

196. Song BL \& DeBose-Boyd RA (2006) Insig-dependent ubiquitination and degradation of 3-hydroxy-3-methylglutaryl coenzyme A reductase stimulated by $\delta$ - and $\gamma$-tocotrienols. J Biol Chem 281, 25054-25061.

197. Chen CW \& Cheng HH (2006) A rice bran oil diet increases LDL-receptor and HMG-CoA reductase mRNA expressions and insulin sensitivity in rats with streptozotocin/nicotinamide-induced type 2 diabetes. J Nutr 136, 1472-1476.

198. Mensink RP, van Houwelingen AC, Kromhout D, et al. (1999) A vitamin E concentrate rich in tocotrienols had no effect on serum lipids, lipoproteins, or platelet function in men with mildly elevated serum lipid concentrations. Am J Clin Nutr 69, 213-219.

199. Mustad VA, Smith CA, Ruey PP, et al. (2002) Supplementation with 3 compositionally different tocotrienol supplements does not improve cardiovascular disease risk factors in men and women with hypercholesterolemia. Am J Clin Nutr 76, 1237-1243.

200. Stevinson C, Pittler MH \& Ernst E (2000) Garlic for treating hypercholesterolemia. A meta-analysis of randomized clinical trials. Ann Intern Med 133, 420-429.

201. Craig WJ (1999) Health-promoting properties of common herbs. Am J Clin Nutr 70, 491S-499S.

202. Tapsell LC, Hemphill I, Cobiac L, et al. (2006) Health benefits of herbs and spices: the past, the present, the future. Med J Aust 185, S4-S24.

203. Ackermann RT, Mulrow CD, Ramirez G, et al. (2001) Garlic shows promise for improving some cardiovascular risk factors. Arch Intern Med 161, 813-824.

204. Gardner CD, Lawson LD, Block E, et al. (2007) Effect of raw garlic vs commercial garlic supplements on plasma lipid concentrations in adults with moderate hypercholesterolemia: a randomized clinical trial. Arch Intern Med 167, 346-353.

205. Reinhart K, Talati R, White C, et al. (2009) The impact of garlic on lipid parameters: a systematic review and metaanalysis. Nutr Res Rev 22, 39-48.

206. Panagiotakos DB, Pitsavos C, Chrysohoou C, et al. (2003) The J-shaped effect of coffee consumption on the risk of developing acute coronary syndromes: the CARDIO2000 case-control study. J Nutr 133, 3228-3232.

207. Christensen B, Mosdol A, Retterstol L, et al. (2001) Abstention from filtered coffee reduces the concentrations of plasma homocysteine and serum cholesterol - a randomized controlled trial. Am J Clin Nutr 74, 302-307.

208. Greenberg JA, Dunbar CC, Schnoll R, et al. (2007) Caffeinated beverage intake and the risk of heart disease mortality in the elderly: a prospective analysis. Am J Clin Nutr 85, 392-398.

209. Bidel S, Hu G, Qiao Q, Jousilahti P, et al. (2006) Coffee consumption and risk of total and cardiovascular mortality among patients with type 2 diabetes. Diabetologia 49, 2618-2626.

210. Miyake Y, Kono S, Nishiwaki M, et al. (1999) Relationship of coffee consumption with serum lipids and lipoproteins in Japanese men. Ann Epidemiol 9, 121-126.
211. Strandhagen E \& Thelle DS (2003) Filtered coffee raises serum cholesterol: results from a controlled study. Eur $J$ Clin Nutr 57, 1164-1168.

212. Cornelis MC \& El-Sohemy A (2007) Coffee, caffeine, and coronary heart disease. Curr Opin Clin Nutr Metab Care 10, 745-751.

213. Cornelis MC, El-Sohemy A, Kabagambe EK, et al. (2006) Coffee, CYP1A2 genotype, and risk of myocardial infarction. JAMA 295, 1135-1141.

214. Sumpio BE, Cordova AC, Berke-Schlessel DW, et al. (2006) Green tea, the 'Asian paradox,' and cardiovascular disease. J Am Coll Surg 202, 813-825.

215. Cooper R, Morré DJ \& Morré DM (2005) Medicinal benefits of green tea: Part I. Review of noncancer health benefits. J Altern Complement Med 11, 521-528.

216. Kuriyama S, Shimazu T, Ohmori K, et al. (2006) Green tea consumption and mortality due to cardiovascular disease, cancer, and all causes in Japan: the Ohsaki study. JAMA 296, 1255-1265.

217. Peters U, Poole C \& Arab I (2001) Does tea affect cardiovascular disease? A meta-analysis. Am J Epidemiol 154, 495-503.

218. Yang CS \& Landau JM (2000) Effects of tea consumption on nutrition and health. J Nutr 130, 2409-2412.

219. McKay DL \& Blumberg JB (2002) The role of tea in human health: an update. J Am Coll Nutr 21, 1-13.

220. Davies MJ, Judd JT, Baer DJ, et al. (2003) Black tea consumption reduces total and LDL cholesterol in mildly hypercholesterolemic adults. J Nutr 133, 3298S-3302S.

221. Nagao T, Meguro S, Hase T, et al. (2009) A catechin-rich beverage improves obesity and blood glucose control in patients with type 2 diabetes. Obesity (Silver Spring) 17, 310-317.

222. Serisier S, Leray V, Poudroux W, et al. (2008) Effects of green tea on insulin sensitivity, lipid profile and expression of PPAR $\alpha$ and PPAR $\gamma$ and their target genes in obese dogs. Br J Nutr 99, 1208-1216.

223. Gouni-Berthold I \& Berthold HK (2002) Policosanol: clinical pharmacology and therapeutic significance of a new lipid-lowering agent. Am Heart J 143, 356-365.

224. Berthold HK, Unverdorben S, Degenhardt R, et al. (2006) Effect of policosanol on lipid levels among patients with hypercholesterolemia or combined hyperlipidemia: a randomized controlled trial. JAMA 295, 2262-2269.

225. Dulin M, Hatcher L, Sasser H, et al. (2006) Policosanol is ineffective in the treatment of hypercholesterolemia: a randomized controlled trial. Am J Clin Nutr 84, 1543-1548.

226. Francini-Pesenti F, Brocadello F, Beltramolli D, et al. (2008) Sugar cane policosanol failed to lower plasma cholesterol in primitive, diet-resistant hypercholesterolaemia: a double blind, controlled study. Complement Ther Med 16, 61-65.

227. Kassis A \& Jones P (2008) Changes in cholesterol kinetics following sugar cane policosanol supplementation: a randomized control trial. Lipids Health Dis 7, 17.

228. Jenkins DJ, Kendall CW, Marchie A, et al. (2005) Direct comparison of a dietary portfolio of cholesterol-lowering foods with a statin in hypercholesterolemic participants. Am J Clin Nutr 81, 380-387.

229. Wang C, Harris W, Chung M, et al. (2006) n-3 Fatty acids from fish or fish-oil supplements, but not $\alpha$-linolenic acid, benefit cardiovascular disease outcomes in primary- and secondary-prevention studies: a systematic review. Am $J$ Clin Nutr 84, 5-17.

230. Uusitupa MI, Ruuskanen E, Makinen E, et al. (1992) A controlled study on the effect of $\beta$-glucan-rich oat bran on 
serum lipids in hypercholesterolemic subjects: relation to apolipoprotein E phenotype. J Am Coll Nutr 11, 651-659.

231. Amundsen AL, Haugum B \& Andersson H (2003) Changes in serum cholesterol and sterol metabolites after intake of products enriched with an oat bran concentrate within a controlled diet. Scand J Nutr 47, 68-74.

232. Braaten J, Wood P, Scott F, et al. (1994) Oat $\beta$-glucan reduces blood cholesterol concentration in hypercholesterolemic subjects. Eur J Clin Nutr 48, 465-474.

233. Anderson J, Spencer D, Hamilton C, et al. (1990) Oat-bran cereal lowers serum total and LDL cholesterol in hypercholesterolemic men. Am J Clin Nutr 52, 495-499.

234. Onning G, Wallmark A, Persson M, et al. (1999) Consumption of oat milk for 5 weeks lowers serum cholesterol and LDL cholesterol in free-living men with moderate hypercholesterolemia. Ann Nutr Metab 43, 301-309.

235. Törrönen R, Kansanen L, Uusitupa M, et al. (1992) Effects of an oat bran concentrate on serum lipids in free-living men with mild to moderate hypercholesterolaemia. Eur J Clin Nutr 46, 621-627.

236. Lovegrove J, Clohessy A, Milon H, et al. (2000) Modest doses of $\beta$-glucan do not reduce concentrations of potentially atherogenic lipoproteins. Am J Clin Nutr 72, 49-55.

237. Kestin M, Moss R, Clifton P, et al. (1990) Comparative effects of three cereal brans on plasma lipids, blood pressure, and glucose metabolism in mildly hypercholesterolemic men. Am J Clin Nutr 52, 661-666.

238. Van Horn L, Moag-Stahlberg A, Liu K, et al. (1991) Effects on serum lipids of adding instant oats to usual American diets. Am J Public Health 81, 183-188.

239. Queenan K, Stewart M, Smith K, et al. (2007) Concentrated oat $\beta$-glucan, a fermentable fiber, lowers serum cholesterol in hypercholesterolemic adults in a randomized controlled trial. Nutr J 6, 6.

240. Kerckhoffs D, Hornstra G \& Mensink R (2003) Cholesterollowering effect of $\beta$-glucan from oat bran in mildly hypercholesterolemic subjects may decrease when $\beta$-glucan is incorporated into bread and cookies. Am J Clin Nutr $\mathbf{7 8}$, 221-227.

241. Reyna-Villasmil N, Bermúdez-Pirela V, Mengual-Moreno E, et al. (2007) Oat-derived $\beta$-glucan significantly improves
HDLC and diminishes LDLC and non-HDL cholesterol in overweight individuals with mild hypercholesterolemia. Am J Ther 14, 203-212.

242. Poulter N, Chang C, Cuff A, et al. (1994) Lipid profiles after the daily consumption of an oat-based cereal: a controlled crossover trial. Am J Clin Nutr 59, 66-69.

243. Turnbull WH \& Leeds AR (1987) Reduction of total and LDL-cholesterol in plasma by rolled oats. J Clin Nutr Gastroenterol 2, 177-181.

244. Whyte J, McArthur R, Topping D, et al. (1992) Oat bran lowers plasma cholesterol levels in mildly hypercholesterolemic men. J Am Diet Assoc 92, 446-449.

245. Gylling H \& Miettinen T (1996) Effects of inhibiting cholesterol absorption and synthesis on cholesterol and lipoprotein metabolism in hypercholesterolemic noninsulin-dependent diabetic men. $J$ Lipid Res 37, 1776-1785.

246. Vanhanen H, Blomqvist S, Ehnholm C, et al. (1993) Serum cholesterol, cholesterol precursors, and plant sterols in hypercholesterolemic subjects with different apoE phenotypes during dietary sitostanol ester treatment. J Lipid Res 34, 1535-1544.

247. Hallikainen M, Sarkkinen E, Gylling H, et al. (2000) Comparison of the effects of plant sterol ester and plant stanol ester-enriched margarines in lowering serum cholesterol concentrations in hypercholesterolaemic subjects on a low-fat diet. Eur J Clin Nutr 54, 715-725.

248. Amundsen A, Ose L, Nenseter M, et al. (2002) Plant sterol ester-enriched spread lowers plasma total and LDL cholesterol in children with familial hypercholesterolemia. Am J Clin Nutr 76, 338-344.

249. Mussner M, Parhofer K, Von Bergmann K, et al. (2002) Effects of phytosterol ester-enriched margarine on plasma lipoproteins in mild to moderate hypercholesterolemia are related to basal cholesterol and fat intake. Metabolism 51, 189-194.

250. Hendriks H, Weststrate J, van Vliet T, et al. (1999) Spreads enriched with three different levels of vegetable oil sterols and the degree of cholesterol lowering in normocholesterolaemic and mildly hypercholesterolaemic subjects. Eur $J$ Clin Nutr 53, 319-327. 